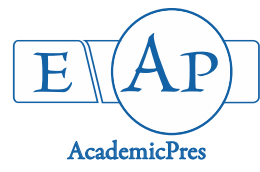

\title{
Floristic Diversity, Vegetation Analysis and Threat Status of Plants in Various Forest Types in Dharmapuri Forest Division, Tamilnadu, Southern India
}

\author{
Umeshkumar L. TIWARI ${ }^{1 *}$, K. RAVIKUMAR ${ }^{2}$ \\ ${ }^{1}$ Botanical Survey of India, Arunachal Pradesh Regional Centre, Senki View, Itanagar-791111, Arunachal Pradesh \\ India; tigerumesh11@gmail.com (" correspondingauthor) \\ ${ }^{2}$ National Herbarium of Medicinal Plants and Repository of Raw Drug, Institute of Trans-disciplinary Health Sciences and Technology (ITD- \\ HST) University; Foundation for Revitalisation of Local Health Traditions (FRLHT), No. 74/2, Jarakabande Kaval, Post Attur, \\ Via-Yelahanka, Bangalore 560 106.ravikumarfrlbt@gmail.com
}

\begin{abstract}
The present paper deals with the study conducted to know the floristic diversity assessment and vegetation composition analysis in various forest types of Dharmapuri Forest division situated in Eastern Ghats of Southern India in the state of Tamilnadu. A total of 352 species of 233 genera and belonging to 79 families were recorded. The quantitative features such as density and important value index (IVI) varied greatly among forest and different forest types. In the present study the diversity index of shrubs and herbs were found to be higher than the tree species. The presence of high number of higher girth class of tree species and low number of sapling and seedling indicates that the present forest is old and exhibiting the low regeneration.
\end{abstract}

Keywords: Dharmapuri Forest Division; floristic diversity; threatened status

\section{Introduction}

Tropical forest constitutes the most diverse plant communities on earth and it cover's $7 \%$ of the earth's land surface, but harbor more than half of the world's species (Wilson, 1988), and are currently vanishing at an overall rate of 0.8-2\% per year (May and Stumpf, 2000; Sagar et al. 2003; Naidu and Kumar, 2015). The vanishing of tropical forests comes at a time when our data on their structure and dynamics is sadly not enough (Hubbell and Foster, 1992). Dependence on forest is inevitable in India, therefore, the pressure on forests by the ever-increasing population in logarithmic (Jayakumar et al., 2002; Pragasan, 2010). Rapidly dwindling biodiversity levels have raised the concern that species loss could sooner or later lead to ecosystem collapse (Naeem and Wright, 2003); a decade of research has highlighted generally a positive relationship (Hooper et al., 2005; Balvanera et al., 2006). India is one of the 12 mega diversity countries in the world. Across the world, 25 hot-spots have been identified on the basis of the species endemism and degree of threat through habitat loss (Mayers et al., 2000). Among the rich biodiversity hot spot areas in India are such as the Eastern and Western Ghats,
Western and Eastern Himalayas and Andaman islands. The present study site falls within the Eastern Ghats.

Hence, the conservation of biological diversity has become a major concern, for much of the society and many government agencies at all levels (Kaya and Raynal, 2001). Documenting basic patterns of biodiversity are fundamental for shows potential areas for conservation and management action (Villasenor et al., 2007). The Eastern Ghats of India is a broken chain of hills that runs almost parallel to east cost of India covering four states viz. Odisa, Andhra Pradesh, Tamilnadu and Karnataka. Floristic diversity and phytosociological study of Dharmapuri forest Division is lacking. Therefore, the present study has been undertaken to assess the plant biodiversity and vegetation analysis in different forest types of Dharmapuri Forest Division.

\section{Materials and Methods}

\section{Study area}

The Dharmapuri Forest Division lies between $11^{\circ} 53^{\prime}$ and $12^{\circ} 29^{\prime} \mathrm{N}$ and $77^{\circ} 40^{\prime}$ and $78^{\circ} 17^{\prime} \mathrm{E}$. It occupies the entire Dharmapuri, Pennagaram and Palacode Talukas. The total area of this division is 9,6407 ha. The headquarters of this division is at Dharmapuri. There are four territorial forest ranges (Pennagaram, Hogenakkal, Dharmapuri and Palakkodu) in this division. 
298

The rainfall is low with annual average of only $846 \mathrm{~mm}$ and varies within the narrow limits from 736 to $1,054 \mathrm{~mm}$.

The division covers a vast table land supported by hill ranges clothing its boundaries on the west, south and east. According to the revised survey of the forest types of India by Champion and Seth (1968), the forest division is represented by 12 different forest types (Fig. 1). The study area is dominated by Southern Tropical Dry Mixed Deciduous forest, Hardwickia subtype, Secondary Dry Deciduous Forest, Dry Deciduous Scrub, Dry Tropical Riverine Forest, Southern Thorn Forest, Southern Thorn Scrub Forest, Dry Bamboo Brake, Carnatic Umbrella Thorn Forest and Southern Euphorbia Scrub.

\section{Survey, sampling, data compilation and analysis}

Survey was conducted during 2013-2015 covering all aspects and different seasons. For the study of plant biodiversity the division is divided based on 10 different forest types. These forest types were further separated depend on topography and altitude. Intensive field survey adopting $0.1 \%$ of the total area of each forest types was carried out following quadrat technique. For the quantitative assessment, a plot of $31.62 \times 31.62 \mathrm{~m}$. ( 65 nos.) quadrats for trees, bamboos and lianas, all the individuals were measured at GBH in the sample plots; within which $5 \times 5 \mathrm{~m}$ (130 nos.) quadrats for shrubs, saplings and climbers and $1 \times 1 \mathrm{~m}$ (260 nos.) quadrats for herbs and seedlings. For the collection of data from these quadrats and analysis, standard ecological methods were followed. A species list of all the identified species was prepared with the help of flora guides (Hooker, 1872-1897; Gamble and Fischer, 19151932; Vajravelu and Radhakrishnan 1967-1968; Matthew, 1981-1984; Ahmedullah and Nayar, 1987; Henry et al., 1987; Henry et al., 1989; Sanjappa, 1992; Nayar, 1996; Jagtap and Singh, 1999; Singh, 2001; Balakrishnan and Chakrabarty, 2007; Ansari, 2008). Each sampled sites were marked with a Global Positioning System (GPS).

Quadrat data were used for computation of analytical features such as density, frequency, basal cover and Important Value Index (IVI), following standards phytosociological methods as given by Curtis and McIntosh (1950). Diameter at breast height of the trees with $>20 \mathrm{~cm}$
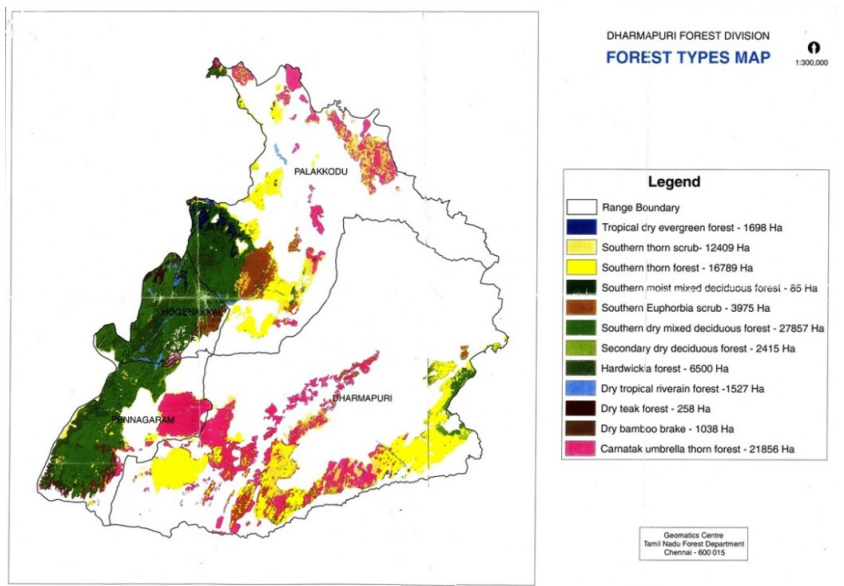

Fig. 1. The Dharmapuri Forest Division (Source: Tamil Nadu Forest Department) circumference in each quadrat was measured and recorded for each species. The Important Value Index (IVI) for the tree species was determined as the sum of the relative density, relative frequency and relative dominance (Simpson, 1949; Curtis, 1959). The species diversity among forest types were determined by using Shannon Wiener information function ( $\left.\mathrm{H}^{\prime}\right)$ (Shannon and Wiener, 1963). Similarity index was determined by as per formula given by Sorenson (1948).

\section{Results and Discussion}

\section{Floristic diversity and threatened status}

The study recorded 352 species of vascular plants of 233 genera belongs to 79 families i.e. Angiosperms (348 species), Pteridophytes ( 3 species) and Bryophytes (1 species) (Table $1 \& 2$ ). Of the total species 51 species were trees, 17 species of Lianas, 42 species of shrubs, 26 species of climbers, 185 species of herbs, sedges 4 , grasses 23 , ferns 2 species and 2 species of mosses. Among these recorded species based on Red data book of Indian Plant (Nayar and Sastry, 1987, 1988, 1990) (Table 2): Three (3) species are Endangered; Two (2) species as Vulnerable; Two (2) species as Near Threatened; Twelve (12) species are Endemic to Southern India. Twenty one (21) species found to be rare.

\section{Compositional features}

\section{Southern tropical dry mixed deciduous forest}

This is the most conspicuous type of deciduous forest in the division spreading over almost all the reserved forests of Palacode and Bevanurmalai of Pennagaram Range. Sandal and Bamboo, the two economically most valuable species are found exclusively in this forest. The species forming the upper and lower canopy are almost deciduous. Some of the predominant trees that are found to occur in this forest type are: Albizia amara, Acacia planifrons, Anogeissus latifolia, Chloroxylon swietenia, Psydrax dicoccus, Cassia fistula, Holoptelea integrifolia, Phyllanthus emblica, Premna tomentosa, Vitex altissima, Cassine glauca, Diospyros ferrea, Strychnos nuxvomica, Shorea talura and Ficus spp. Shorea talura though occurs profusely in this sub type, but only in patches. The most common climbers/liana/straggler in this forest is: Cissus quadrangularis, Cocculus hirsutus, Scutia myrtina, Cryptolepis grandiflora, Jasminum spp., etc. The common herbs here are Spermacoce ocymoides, Evolvulus alsinoides, Oplismenus compositus, Aristida setacea etc.

Tree layer: In this forest type Albizia amara has highest density (179.9 $\mathrm{ha}^{-1}$ ) and IVI (32.2) was recorded followed by Acacia planifrons $\left(\mathrm{D}=105.4 \mathrm{ha}^{-1}\right.$ and IVI= 25.3) (Appendix 1).

Sapling and seedlings: In sapling (of tree species) stage Acacia planifrons was dominant among all other species present in this forest type followed by Albizia amara. Shrub layer: Acalypha fruticosa $\left(\mathrm{D}=1,820 \mathrm{ha}^{-1}, \mathrm{IVI}=30.05\right)$, Tarenna asiatica $\left(\mathrm{D}=1,000 \mathrm{ha}^{-1}, \mathrm{IVI}=18.80\right)$, Solanum pubescens $\left(\mathrm{D}=860 \mathrm{ha}^{-1}, \mathrm{IVI}=17.29\right)$ and Lantana camara $\left(\mathrm{D}=860 \mathrm{ha}^{-1}\right.$, IVI=16.93). The highest frequency was recorded for Coffea wightiana ( $\mathrm{f}=40 \%$ ) followed by Solanum pubescens $(\mathrm{f}=35 \%)$. The frequency ranged from $5-40 \%$. 
Table 1. Floristic diversity in various forest types of Dharmapuri Forest (DFD)

\begin{tabular}{|c|c|c|c|c|c|c|c|c|c|c|c|}
\hline Habits & CUTF & DDS & $\mathrm{EuS}$ & HwkF & $\mathrm{RvF}$ & SDDF & SDMDF & SDS & STF & STS & DFD \\
\hline Trees & 21 & 13 & 10 & 7 & 9 & 10 & 29 & 15 & 23 & 23 & 51 \\
\hline Liana & 7 & 4 & 3 & 2 & 4 & 5 & 13 & 5 & 9 & 6 & 17 \\
\hline Shrubs & 25 & 13 & 11 & 0 & 3 & 19 & 25 & 14 & 20 & 20 & 42 \\
\hline Climbers & 16 & 7 & 7 & 1 & 0 & 9 & 12 & 9 & 12 & 13 & 26 \\
\hline Herbs & 109 & 46 & 36 & 9 & 15 & 76 & 55 & 60 & 103 & 88 & 185 \\
\hline Grass & 12 & 4 & 3 & 1 & 1 & 11 & 5 & 6 & 12 & 13 & 23 \\
\hline Sedges & 2 & 2 & 1 & 0 & 0 & 1 & 3 & 1 & 3 & 3 & 4 \\
\hline Fern & 3 & 2 & 0 & 0 & 0 & 1 & 1 & 2 & 3 & 0 & 3 \\
\hline Moss & 1 & 1 & 0 & 0 & 0 & 1 & 1 & 0 & 0 & 1 & 1 \\
\hline Total species & 196 & 92 & 71 & 20 & 32 & 133 & 144 & 112 & 185 & 167 & 352 \\
\hline Number Genera & 134 & 81 & 63 & 20 & 32 & 101 & 119 & 90 & 140 & 126 & 233 \\
\hline Number of Family & 58 & 41 & 37 & 17 & 23 & 49 & 52 & 43 & 51 & 50 & 79 \\
\hline $\mathrm{EN}$ & 2 & 1 & 2 & 0 & 0 & 2 & 2 & 2 & 3 & 3 & 3 \\
\hline Endemic (SI or PI) & 8 & 2 & 0 & 2 & 0 & 5 & 2 & 3 & 5 & 5 & 12 \\
\hline NT & 0 & 1 & 1 & 1 & 1 & 0 & 1 & 0 & 0 & 0 & 2 \\
\hline Rare & 8 & 1 & 1 & 0 & 0 & 4 & 5 & 1 & 10 & 3 & 21 \\
\hline $\mathrm{VL}$ & 1 & 0 & 0 & 0 & 1 & 0 & 2 & 1 & 1 & 1 & 2 \\
\hline
\end{tabular}

1. CUTF: Carnatic Umbrella Thorn Forest; 2. DDS: Dry Deciduous Scrub Forest; 3. EuS: Euphorbia Scrub Forest; 4. HwkF: Hardwickia Forest; 5 . RvF: Riverain Forest; 6. SDDF: Southern Tropical Dry Deciduous Forest; 7. SDMDF: Southern Tropical Dry Moist Mixed Deciduous Forest; 8. SDS: Southern Scrub Forest; 9. STF: Southern Thorn Forest; 10. STS: Southern Thorn Scrub Forest; EN: Endangered; SI: Southern India or PI: Peninsular India; NT: Near Threatened; VN: Vulnerable.

Herb layer: The density ranged from $6.63 / \mathrm{m}^{2}$ to $0.03 / \mathrm{m}^{2}$, grasses exhibits $13.88 \%$ of each plots. Among grasses Oropetium thomaeum $\left(\mathrm{D}=2.5 / \mathrm{m}^{2}\right)$, Aristida setacea $\left(\mathrm{D}=2.0 / \mathrm{m}^{2}\right)$, Eragrastirella $\mathrm{sp} .\left(\mathrm{D}=1.08 / \mathrm{m}^{2}\right)$ followed by Oplismenus composites $\left(\mathrm{D}=1.0 / \mathrm{m}^{2}\right)$. Mitracarpus hirtus exhibits the maximum density $\left(D=6.43 / \mathrm{m}^{2}\right)$ and $\mathrm{F}=47.50 \%$, followed by Spermacoce ocymoides $\left(\mathrm{D}=4.75 / \mathrm{m}^{2}\right.$ and $\mathrm{F}=55 \%)$, Evolvulus alsinoides $\left(\mathrm{D}=3.68 / \mathrm{m}^{2}\right.$ and $\mathrm{F}=72.50 \%)$ and Spermacoce articularis $\left(\mathrm{D}=3.50 / \mathrm{m}^{2}\right.$ and $\mathrm{F}=32.50 \%$ ). The highest frequency was recorded for Evolvulus alsinoides $(72.50 \%)$ and lowest for many species with $2.5 \%$. Hardwickia subtype: Under Dry Deciduous forest, this sub types very distinct. This classification is based on the abundant presence of Hardwickia binata. This tree occurs gregariously and is often occupies the slopes that drain into the Cauvery, Chinnar and Anaibiddahalla on the west and Hosur valley in the east. Since this species is of evergreen nature, it stands out conspicuously in this sub type. Some of the other associated species are: Boswellia serrata, Grewia flavescens, Solanum pubescens, Grewia tenax, Chloroxylon swietenia, Dichrostachys cinerea and Diospyros spp. Tree layer: In this forest type the climax species is Hardwickia binata has highest density $\left(138.86 \mathrm{ha}^{-1}\right)$ and IVI (120.89) was recorded followed by Gyrocarpus americanus $\left(\mathrm{D}=69.43 \mathrm{ha}^{-1}\right.$ and IVI= 54.63) and Albizia amara $(\mathrm{D}=$ $69.43 \mathrm{ha}^{-1}$ and IVI= 46.93) (Appendix 1). Sapling and seedlings: In sapling (of tree species) stage Albizia amara was dominant among all other species present in this forest type followed by Holoptelea integrifolia and Hardwickia binata. Shrub layer: Acalypha fruticosa $\left(\mathrm{D}=1,820 \mathrm{ha}^{-1}, \mathrm{IVI}=30.05\right)$, Tarenna asiatica $\left(\mathrm{D}=1,000 \mathrm{ha}^{-1}, \mathrm{IVI}=18.80\right)$, Solanum pubescens $\left(\mathrm{D}=860 \mathrm{ha}^{-1}, \mathrm{IVI}=17.29\right)$ and Lantana camara $\left(\mathrm{D}=860 \mathrm{ha}^{-1}, \mathrm{IVI}=16.93\right)$. The highest frequency was recorded for Coffea wightiana ( $\mathrm{f}=40 \%$ ) followed by Solanum pubescens $(\mathrm{f}=35 \%)$. The frequency ranged from 5 $40 \%$.

Herb layer: The density ranged from $6.63 / \mathrm{m}^{2}$ to $0.03 / \mathrm{m}^{2}$, grasses exhibits $13.88 \%$ of each plots. Among grasses Oropetium thomaeum $\left(\mathrm{D}=2.5 / \mathrm{m}^{2}\right)$, Aristida setacea $\left(\mathrm{D}=2.0 / \mathrm{m}^{2}\right)$, Eragrastirella sp. $\left(\mathrm{D}=1.08 / \mathrm{m}^{2}\right)$ followed by Oplismenus composites $\left(\mathrm{D}=1.0 / \mathrm{m}^{2}\right)$. Mitracarpus hirtus exhibits the maximum density $\left(D=6.43 / \mathrm{m}^{2}\right)$ and $\mathrm{F}=47.50 \%$, followed by Spermacoce ocymoides $\left(\mathrm{D}=4.75 / \mathrm{m}^{2}\right.$ and $\mathrm{F}=55 \%)$, Evolvulus alsinoides $\left(\mathrm{D}=3.68 / \mathrm{m}^{2}\right.$ and $\mathrm{F}=72.50 \%)$ and Spermacoce articularis $\left(\mathrm{D}=3.50 / \mathrm{m}^{2}\right.$ and $\mathrm{F}=32.50 \%$ ). The highest frequency was recorded for Evolvulus alsinoides (72.50\%) and lowest for many species with 2.5\%. Secondary Dry Deciduous Forest: Basically this is a mixed deciduous forest but due to continuous exploitation and biotic interferences it is converted in to secondary serial forest type. This forest is dominated by Albizia amara and other associate species are: Acalypha fruticosa, Solanum pubescens, Gymnema sylvestre, Jasminum spp. Pachygone ovata, Gyrocarpus americanus, Cordia monoica, Fluggea leucopyrus, Ziziphus trinervia, Chloroxylon swietenia, Dichrostachys cinerea and Moringa concanensis. In this forest type the climax species is Albizia amara has highest density (311 ha $\mathrm{h}^{-1}$ ) and IVI (179) was recorded followed by Pterolobium hexapetalum $\left(\mathrm{D}=31 \mathrm{ha}^{-1}\right.$ and IVI= 12.3), Chloroxylon swietenia $\left(\mathrm{D}=27 \mathrm{ha}^{-1}\right.$ and $\left.\mathrm{IVI}=20.80\right)$ and Euphorbia antiquorum $\left(\mathrm{D}=25 \mathrm{ha}^{-1}\right.$ and IVI= 16.4) (Appendix 1). Sapling and seedlings: In sapling (of tree species) stage Albizia amara was dominant among all other species present in this forest type followed by Chloroxylon swietenia and Flueggea leucopyrus. Shrub layer: Solanum pubescens $\left(\mathrm{D}=4072.73 \mathrm{ha}^{-1}, \mathrm{IVI}=45.33\right)$, Acalyph a fruticosa 
300

$\left(\mathrm{D}=2654.55 \mathrm{ha}^{-1}, \quad \mathrm{IVI}=31.41\right), \quad$ Lantana camara $\left(\mathrm{D}=1290.91 \mathrm{ha}^{-1}, \mathrm{IVI}=19.22\right)$ and Jatropha gossypiifolia $\left(\mathrm{D}=860 \mathrm{ha}^{-1}, \mathrm{IVI}=16.93\right)$. The highest frequency was recorded for Solanum pubescens $(\mathrm{F}=72.73 \%)$ followed by Acalypha fruticosa and Lantana camara (f=40.91\%). The frequency ranged from $4.5-72.73 \%$. Herb layer: The density ranged from $6.63 / \mathrm{m}^{2}$ to $0.03 / \mathrm{m}^{2}$, grasses exhibits $13.88 \%$ of each plots. Among the dominant species Aristida adscensionis $\left(\mathrm{D}=4.84 / \mathrm{m}^{2}\right)$, Abutilon crispum $\left(\mathrm{D}=3.16 / \mathrm{m}^{2}\right)$, Blepharis molluginifolia $\left(\mathrm{D}=2.66 / \mathrm{m}^{2}\right)$ followed by Sida cordifolia $\left(\mathrm{D}=2.55 / \mathrm{m}^{2}\right)$. Blepharis molluginifolia exhibits the maximum frequency $=75 \%$, followed by Justicia glauca ( $\mathrm{F}=56.82 \%)$, Justicia prostrata $(\mathrm{F}=45.45 \%)$ and Aristida adscensionis $(\mathrm{F}=40.91 \%)$ and lowest frequency for many species with $2.27 \%$.

Dry Deciduous Scrub Forest: Due to persistent felling and removal of useful species this forest type was subjected to a high degree of degradation over a prolonged period of time, by which all the tall trees eventually disappeared, resulting in to stunted growth of few scattered trees seen in open forest. Some of the common species composition are: Albizia amara, Chloroxylon swietenia, Dichrostachys cinerea, Diospyros spp., Cipadessa baccifera, Atalantia monophylla, Annona squamosa, Butea monosperma, Wrightia tinctoria, Feronia elephantum, Dodonaea viscosa, Catunaregum spinosa, Pavetta indica, Lantana camara, Ziziphus mauritiana, Gymnema sylvestre, Cassia montana, Azadirachta indica, Hemidesmus indicus, Ichnocarpus frutescsens, etc. In this forest type the climax species is Azadirachta indica has highest density (139 ha $\mathrm{h}^{-1}$ ) and IVI (131.4) was recorded followed by Toddalia asiatica var. gracilis $\left(\mathrm{D}=56.80 \mathrm{ha}^{-1}\right.$ and $\left.\mathrm{IVI}=20.26\right)$, Chloroxylon swietenia $\left(\mathrm{D}=53.6 \mathrm{ha}^{-1}\right.$ and $\left.\mathrm{IVI}=25.11\right)$, Albizia amara $\left(\mathrm{D}=47.33 \mathrm{ha}^{-1}\right.$ and $\left.\mathrm{IVI}=22.5\right)$ and Erythroxylum monogynum $\left(\mathrm{D}=37.9 \mathrm{ha}^{-1}\right.$ and $\left.\mathrm{IVI}=20.05\right)$ (Appendix 1).

Sapling and seedlings: In sapling (of tree species) stage Azadirachta indica was dominant among all other species present in this forest type followed by Wrightia tinctoria, Chloroxylon swietenia and Euphorbia antiquorum. Shrub layer: Dodonaea viscosa $\left(\mathrm{D}=7866.67 \mathrm{ha}^{-1}, \mathrm{~F}=83.33 \%, \mathrm{IVI}=\right.$ 45.67), Lantana camara (D= 5,200 ha ${ }^{-1}, \mathrm{~F}=66.67 \%$, IVI= 33.41), Canthium coromandelicum $\left(\mathrm{D}=3,066.67 \mathrm{ha}^{-1}, \mathrm{~F}=\right.$ $50 \%$, IVI= 22.78), Flueggea leucopyrus $\left(\mathrm{D}=3,000 \mathrm{ha}^{-1}, \mathrm{~F}=\right.$ $50 \%, \mathrm{IVI}=22.42$ ). The lowest density, frequency and IVI was recorded for Annona squamosa, Aristolochia indica, Cocculus hirsutus and Cryptolepis grandiflora $\left(\mathrm{D}=66.67 \mathrm{ha}^{-1}\right.$, $\mathrm{F}=16.67 \%, \mathrm{IVI}=2.75)$. The frequency ranged from 16.67 83.33\%.

Herb layer: The density ranged from $6.63 / \mathrm{m}^{2}$ to $0.03 /$ $\mathrm{m}^{2}$, grasses exhibits $13.88 \%$ of each plots. Brachiaria ramosa $\left(\mathrm{D}=36.67 / \mathrm{m}^{2}, \mathrm{~F}=50 \%\right)$, Spermacoce ocymoides $(\mathrm{D}=27.67 /$ $\left.\mathrm{m}^{2}, \mathrm{~F}=25 \%\right)$, Glossocardia bosvallia $\left(\mathrm{D}=3.67 / \mathrm{m}^{2}, \mathrm{~F}=\right.$ $8.33 \%)$ followed by Polygala chinensis $\left(\mathrm{D}=2.50 / \mathrm{m}^{2}, \mathrm{~F}=\right.$ $25 \%)$.

Dry Tropical Riverain forests: This forest type is particularly noticeable along Cauvery and Chinnar rivers near Hogenakkal. The most predominant and unique tree species of this type are Terminalia arjuna mixed with
Syzygium cumini, Pongamia pinnata, Mangifera indica, Barringtonia acutangula, Alangium salvifolium, Ficus racemosa, Sapindus emarginatusand Tamarindus indica. Other life forms such as Crinum asiaticum, Homonaia retusa, Cyperus sp. and Citrullus colocynthis are also seen in this forest type. In this forest type the climax species is Prosopis juliflora has highest density $\left(104.14 \mathrm{ha}^{-1}\right)$ and IVI (12.58) was recorded followed by Albizia amara $(\mathrm{D}=47.34$ $\mathrm{ha}^{-1}$ and IVI= 47.12), Terminalia arjuna $\left(\mathrm{D}=28.40 \mathrm{ha}^{-1}\right.$ and IVI=19.92), Syzygium cumini $\left(\mathrm{D}=18.93 \mathrm{ha}^{-1}\right.$ and IVI= 16.58) and Sapindus emarginatus and Pongamia glabra (D= $18.93 \mathrm{ha}^{-1}$ and IVI=19.80, 19.41 respectively) (Appendix $1)$.

Sapling and seedlings: In sapling (of tree species) stage Prosopis juliflora was dominant among all other species present in this forest type followed by Syzygium cumini, Terminalia arjuna and Pongamia glabra. Shrub layer: Barleria prionitis $\left(\mathrm{D}=1000 \mathrm{ha}^{-1}, \mathrm{~F}=100 \%, \mathrm{IVI}=76.1\right)$, Azima tetracantha $\left(\mathrm{D}=600 \mathrm{ha}^{-1}, \mathrm{~F}=100 \%, \mathrm{IVI}=53.6\right)$, Cocculus villosus $\left(\mathrm{D}=400 \mathrm{ha}^{-1}, \mathrm{~F}=50 \%, \mathrm{IVI}=41.5\right)$, Jatropha gossypifolia ( $\mathrm{D}=200 \mathrm{ha}^{-1}, \mathrm{~F}=50 \%$, IVI= 25.8). Herb layer: The density ranged from $13 / \mathrm{m}^{2}$ to $0.75 / \mathrm{m}^{2}$, grasses exhibits $2.50 \%$ of each plots. Maximum density was recorded for Spilanthes clava $\left(\mathrm{D}=18 / \mathrm{m}^{2}, \mathrm{~F}=50 \%\right)$, Achyranthes aspera $\left(\mathrm{D}=13 / \mathrm{m}^{2}, \mathrm{~F}=25 \%\right)$, Sida acuta $\left(\mathrm{D}=10.5 / \mathrm{m}^{2}, \mathrm{~F}=25 \%\right)$, Crossandra linneari $\left(\mathrm{D}=7.50 / \mathrm{m}^{2}\right.$, $\mathrm{F}=50 \%)$, Leonotis nepetifolia $\left(\mathrm{D}=6.25 / \mathrm{m}^{2}, \mathrm{~F}=25 \%\right)$ followed by Aerva lanata ( $\left.\mathrm{D}=5.0 / \mathrm{m}^{2}, \mathrm{~F}=25 \%\right)$.

Southern Thorn Forests: This type of forest occurs mostly in the southern western part of the division covering entire Dharmapuri range. Floristically it is dominated by Albizia amara, Chloroxylon swietenia, Azadirachta indica, Psydrax dicoccus, Erythroxylon monogynum, Cassia montana, Flacourtia indica, Maytenus emarginatus, Naringi crenulata, Balanites aegyptiaca, Toddalia asiatica var. gracilis, Gymnema sylvestre, Acacia chundra, Acacia leucophloea, Acacia ferruginea, Ziziphus xylopyrus and Dichrostachys cinerea. This forest type is dominated by Albizia amara $(\mathrm{D}=$ $\left.77.63 \mathrm{ha}^{-1}, \mathrm{~F}=80 \%, \mathrm{IVI}=48.48\right)$ followed by Chloroxylon swietenia $\left(\mathrm{D}=53.96 \mathrm{ha}^{-1} \mathrm{~F}=60 \%, \mathrm{IVI}=31.28\right)$, Acacia planifrons $\left(\mathrm{D}=46.39 \mathrm{ha}^{-1} \mathrm{~F}=40 \%, \mathrm{IVI}=52.03\right)$, Acacia chundra $\left(\mathrm{D}=39.76 \mathrm{ha}^{-1}, \mathrm{~F}=40 \%, \mathrm{IVI}=26.11\right)$, Acacia leucophloea $\left(\mathrm{D}=31.24 \mathrm{ha}^{-1} \mathrm{~F}=50 \%, \mathrm{IVI}=22.97\right)$ and Pterolobium hexapetalum $\left(\mathrm{D}=22.72 \mathrm{ha}^{-1}, \mathrm{~F}=50 \%\right.$, IVI= 11.47) (Appendix 1).

Sapling and seedlings: In sapling (of tree species) stage Acacia planifrons was dominant among all other species present in this forest type followed by Pterolobium bexapetalum, Acacia chundra and Albizia amara, Euphorbia antiquorum and Euphorbia tortilis. Shrub layer: Lantana camara $\left(\mathrm{D}=2500 \mathrm{ha}^{-1}, \mathrm{~F}=50 \%, \mathrm{IVI}=24.22\right)$, Dodonaea viscosa $\left(\mathrm{D}=1880 \mathrm{ha}^{-1}, \mathrm{~F}=40 \%, \mathrm{IVI}=19.40\right)$, Cassia montana $\left(\mathrm{D}=1720 \mathrm{ha}^{-1}, \mathrm{~F}=35 \%, \mathrm{IVI}=18.13\right)$, Tarenna asiatica $\left(\mathrm{D}=1620 \mathrm{ha}^{-1}, \mathrm{~F}=65 \%, \mathrm{IVI}=19.02\right)$ and Flueggea leucopyrus $\left(\mathrm{D}=1080 \mathrm{ha}^{-1}, \mathrm{~F}=35 \%, \mathrm{IVI}=12.99\right)$. Seven (07) species with lowest density, frequency and IVI $\left(D=20 \mathrm{ha}^{-1}\right.$, $\mathrm{F}=5 \%, \mathrm{IVI}=1.10)$. The frequency ranged from $5-65 \%$. 
Herb layer: The density ranged from $7.88 / \mathrm{m}^{2}$ to $0.05 / \mathrm{m}^{2}$, dominant species are Aristida setacea $\left(\mathrm{D}=7.88 / \mathrm{m}^{2}\right.$, $\mathrm{F}=50 \%)$, Evolvulus alsinoides $\left(\mathrm{D}=7.48 / \mathrm{m}^{2}, \mathrm{~F}=77.50 \%\right)$, Glossocardia bosvallia $\left(\mathrm{D}=6.25 / \mathrm{m}^{2}, \mathrm{~F}=12.50 \%\right)$, Barleria buxifolia $\left(\mathrm{D}=6.0 / \mathrm{m}^{2}, \mathrm{~F}=52.50 \%\right)$, Aristida adscensionis $\left(\mathrm{D}=5.25 / \mathrm{m}^{2}, \mathrm{~F}=87.5 \%\right)$ followed by Fimbristylis ovata $\left(\mathrm{D}=3.75 / \mathrm{m}^{2}, \mathrm{~F}=37.50 \%\right)$.

Southern Thorn Scrub: When the thorn forests are repeatedly hacked at higher intensity these forests are reduced to a mere scrub land consisting of thorny bushes and stunted tree growth averaging to 2 to 3 meters in height. Impenetrable thorny thickets also are commonly met within this type of forests. This forest is usually represented by species like Albizia amara, Chloroxylon swietenia, Azadirachta indica, Psydrax dicoccus, Toddalia asiatica var. gracilis, Pterolobium bexapetalum, Erythroxylon monogynum, Dodonaea viscosa, Acacia caesia, Acacia chundra, Acacia ferruginea, Ziziphus xylopyrus, Dichrostachys cinerea, Lantana camera and Caralluma adscendens var. attenuata. This forest type is dominated by Chloroxylon swietenia $\left(\mathrm{D}=29.59 \mathrm{ha}^{-1}, \mathrm{~F}=62.50 \%, \mathrm{IVI}=24.16\right)$ followed by Pterolobium hexapetalum $\left(\mathrm{D}=29.59 \mathrm{ha}^{-1}, \mathrm{~F}=62.50 \%\right.$, $\mathrm{IVI}=22.90)$, Acacia chundra $\left(\mathrm{D}=27.22 \mathrm{ha}^{-1}, \mathrm{~F}=37.50 \%\right.$, $\mathrm{IVI}=23.95)$, Tamarindus indica $\left(\mathrm{D}=22.49 \mathrm{ha}^{-1} \mathrm{~F}=\right.$ $12.50 \%, \mathrm{IVI}=99.41)$ and Albizia amara $\left(\mathrm{D}=17.75 \mathrm{ha}^{-1}, \mathrm{~F}=\right.$ 50\%, IVI= 15.53) (Appendix 1).

Sapling and seedlings: In sapling (of tree species) stage Chloroxylon swietenia, Acacia planifrons, Acacia chundra was dominant among all other species present in this forest type followed by Pterolobium hexapetalum, Albizia amara, Euphorbia antiquorum and Ziziphus oenoplia. Shrub layer: Lantana camara $\left(\mathrm{D}=3,825 \mathrm{ha}^{-1}, \mathrm{~F}=75 \%\right.$, IVI= 29.05), Dodonaea viscosa $\left(\mathrm{D}=3450 \mathrm{ha}^{-1}, \mathrm{~F}=56.25 \%, \mathrm{IVI}=26.11\right)$, Cassia montana $\left(\mathrm{D}=2,300 \mathrm{ha}^{-1}, \mathrm{~F}=43.75 \%, \mathrm{IVI}=19.16\right)$, Catunaregam spinosa $\left(\mathrm{D}=2,100 \mathrm{ha}^{-1}, \mathrm{~F}=50 \%, \mathrm{IVI}=18.21\right)$, Tarenna asiatica $\left(\mathrm{D}=1,250 \mathrm{ha}^{-1}, \mathrm{~F}=37.5 \%, \mathrm{IVI}=12.49\right)$ and Flueggea leucopyrus ( $\mathrm{D}=1,825 \mathrm{ha}^{-1}, \mathrm{~F}=62.50 \%$, IVI= 17.54). Five (05) species with lowest density, frequency and IVI $\left(\mathrm{D}=20 \mathrm{ha}^{-1}, \mathrm{~F}=6.25 \%, \mathrm{IVI}=1.20\right)$. The frequency ranged from $6.25-75 \%$.

Herb layer: The density ranged from $12.66 / \mathrm{m}^{2}$ to $0.03 / \mathrm{m}^{2}$, dominant species are Digitaria bicornis $\left(\mathrm{D}=12.66 / \mathrm{m}^{2}, \quad \mathrm{~F}=31.25 \%\right), \quad$ Brachiaria ramosa $\left(\mathrm{D}=11.09 / \mathrm{m}^{2}, \quad \mathrm{~F}=34.38 \%\right), \quad$ Evolvulus alsinoides $\left(\mathrm{D}=7.75 / \mathrm{m}^{2}, \mathrm{~F}=21.88 \%\right)$, Hedyotis puberula $\left(\mathrm{D}=4.19 / \mathrm{m}^{2}\right.$, $\mathrm{F}=15.63 \%)$, Spermacoce articularis $\left(\mathrm{D}=2.72 / \mathrm{m}^{2}, \quad \mathrm{~F}=\right.$ $12.50 \%)$ followed by Digitaria ciliaris $\left(\mathrm{D}=2.50 / \mathrm{m}^{2}, \mathrm{~F}=\right.$ $9.38 \%)$.

Carnatic Umbrella Thorn Forest (CUTF): This vegetation is of open thorny forests with scattered Acacia planifrons and Albizia amara that are characterized by umbrella-shaped crowns. Other floristic elements seen in this forest type are: Acalypha fruticosa, Holoptelea integrifolia, Dodonaea viscosa, Solanum pubescens, Cocculus hirsutus, Cissus quadrangularis, Cryptolepis grandiflora, Abutilon crispum, Sarcostemma acidum, Sida spp., Dioscorea spp., Corallocarpus epigaeus, Cardiospermum canescens, Barleia longiflora, Gymnema sylvestre, etc. In CUTF forest a total of 196 species were recorded.
Tree layer: In this forest type 21 tree species and 7 lianas were recorded, dominated species in this forest are Acacia planifrons $\left(\mathrm{D}=185.81 \mathrm{ha}^{-1}, \mathrm{~F}=100 \%, \mathrm{IVI}=126.24\right)$, Albizia amara $\left(\mathrm{D}=125.98 \mathrm{ha}^{-1}, \mathrm{~F}=92.86 \%, \quad \mathrm{IVI}=57.97\right)$, Pterolobium bexapetalum ( $\mathrm{D}=35.84 \mathrm{ha}^{-1}, \mathrm{~F}=64.29 \%$, IVI=15.91), Flueggea leucopyrus $\left(\mathrm{D}=21.71 \mathrm{ha}^{-1}, \mathrm{~F}=14.29 \%\right.$, $\mathrm{IVI}=7.35)$, Wrightia tinctoria $\left(\mathrm{D}=16.23 \mathrm{ha}^{-1}, \mathrm{~F}=50 \%\right.$, IVI=9.92), Euphorbia antiquorum $\left(\mathrm{D}=13.71 \mathrm{ha}^{-1}\right.$, $\mathrm{F}=42.86 \%, \mathrm{IVI}=8.49)$, Chloroxylon swietenia $\left(\mathrm{D}=12.30\right.$ ha $^{-}$ $\left.{ }^{1}, \mathrm{~F}=28.57 \%, \mathrm{IVI}=6.35\right)$ and Annona squamosa $(\mathrm{D}=11.50$ $\left.\mathrm{ha}^{-1}, \mathrm{~F}=28.57 \%, \mathrm{IVI}=6.10\right)$.

Shrub layer: In this forest type 25 species of shrubs and 16 species of climbers and lianas were recorded, among these dominant species are Acalypha fruticosa (D=4173.33 $\mathrm{ha}^{-1}$, $\mathrm{F}=40 \%$, IVI=34.2), Lantana camera $\left(\mathrm{D}=1800 \mathrm{ha}^{-1}\right.$, $\mathrm{F}=60 \%$, IVI=19.6), Solanum pubescens $\left(\mathrm{D}=1413.33 \mathrm{ha}^{-1}\right.$, $\mathrm{F}=53.33 \%, \mathrm{IVI}=16.45)$, Jatropha gossipiifolia $(\mathrm{D}=1106.67$ $\left.\mathrm{ha}^{-1}, \mathrm{~F}=40 \%, \mathrm{IVI}=13.1\right)$, Flueggea leucopyrus $\left(\mathrm{D}=1040 \mathrm{ha}^{-1}\right.$, $\mathrm{F}=40 \%$, IVI $=12.7)$, Tarenna asiatica $\left(\mathrm{D}=880 \mathrm{ha}^{-1}\right.$, $\mathrm{F}=26.67 \%, \mathrm{IVI}=10.5)$, Jasminum angustifolium $(\mathrm{D}=613.33$ $\left.\mathrm{ha}^{-1}, \mathrm{~F}=33.33 \%, \mathrm{IVI}=9.02\right)$ and Opuntia dillenii $(\mathrm{D}=600 \mathrm{ha}$ , $\mathrm{F}=16.67 \%$, IVI=7.88).

Herb layer: Among herbaceous species grasses are dominant in ground cover in this forest type. Aristida adscensionis $\left(\mathrm{D}=6.35 \mathrm{ha}^{-1}, \mathrm{~F}=46.67 \%\right)$, Evolvulus alsinoides $\left(\mathrm{D}=5.43 \mathrm{ha}^{-1}, \mathrm{~F}=53.33 \%\right)$, Oropetium thomaeum $(\mathrm{D}=5.28$ $\left.\mathrm{ha}^{-1}, \mathrm{~F}=33.33 \%\right)$, Brachiaria ramosa $\left(\mathrm{D}=4.78 \mathrm{ha}^{-1}\right.$, $\mathrm{F}=23.33 \%)$, Spermacoce ocymoides ( $\left.\mathrm{D}=4.33 \mathrm{ha}^{-1}, \mathrm{~F}=30 \%\right)$, Indigofera linnaei $\left(\mathrm{D}=4.17 \mathrm{ha}^{-1}, \mathrm{~F}=46.67 \%\right)$, Spermacoce stricta $\left(\mathrm{D}=4.0 \mathrm{ha}^{-1}, \mathrm{~F}=33.33 \%\right)$, Hibiscus lobatus $(\mathrm{D}=3.92$ $\left.\mathrm{ha}^{-1}, \mathrm{~F}=43.33 \%\right)$, Spermacoce articularis $\left(\mathrm{D}=3.52 \mathrm{ha}^{-1}\right.$, $\mathrm{F}=18.33 \%)$ and Sida cordifolia $\left(\mathrm{D}=2.97 \mathrm{ha}^{-1}, \mathrm{~F}=53.33 \%\right)$.

Southern Euphorbia Scrub: This is an extremely degraded type of forest seen in pockets along the fringes of the Carnatic Ambrella Thorn Forests. No noteworthy tree growths are seen here. The vegetation comprises mostly Euphorbia antiquorum, Euphorbia tortilis with Albizia amara, Azadirachta indica and Annona squamosa. Some of the worthy species to be mentioned in this forest type are: Coccinea indica, Caralluma spp., Rhynchosia minima, Sida spp., Commiphora berryi, Dioscorea spp., Cardiospermum halicacabum, Barleria buxifolia, etc.

Tree layer: This forest is dominated by Acacia planifrons $\left(\mathrm{D}=138.86 \mathrm{ha}^{-1}, \mathrm{~F}=100 \%, \quad \mathrm{IVI}=84.80\right), \quad$ Euphorbia antiquorum $\left(\mathrm{D}=88.36 \mathrm{ha}^{-1}, \mathrm{~F}=100 \%, \mathrm{IVI}=48.65\right)$, Annona squamosa $\left(\mathrm{D}=82.05 \mathrm{ha}^{-1}, \mathrm{~F}=33.33 \%, \mathrm{IVI}=45.97\right)$, Albizia amara $\left(\mathrm{D}=41.03 \mathrm{ha}^{-1}, \mathrm{~F}=33.33 \%, \quad \mathrm{IVI}=29.06\right)$, Commiphora berryi $\left(\mathrm{D}=25.25 \mathrm{ha}^{-1}, \mathrm{~F}=66.67 \%\right.$, IVI=15.36), Dichrostachys cinerea $\left(\mathrm{D}=22.09 \mathrm{ha}^{-1}\right.$, $\mathrm{F}=33.33 \%$, IVI=10.08), Capparis sepiaria $\left(\mathrm{D}=12.62 \mathrm{ha}^{-1}\right.$, $\mathrm{F}=33.33 \%$, IVI=7.63), Flacourtia indica $\left(\mathrm{D}=12.62 \mathrm{ha}^{-1}\right.$, $\mathrm{F}=33.33 \%, \mathrm{IVI}=7.46)$ and Toddalia asiatica var. gracilis $\left(\mathrm{D}=12.62 \mathrm{ha}^{-1}, \mathrm{~F}=33.33 \%, \mathrm{IVI}=7.60\right)$.

Shrub layer: Among these dominant species are Opuntia dillenii ( $\mathrm{D}=2,600 \mathrm{ha}^{-1}, \mathrm{~F}=50 \%$, IVI=31.23), Acalypha fruticosa $\left(\mathrm{D}=1,866.67 \mathrm{ha}^{-1}, \mathrm{~F}=33.33 \%, \quad \mathrm{IVI}=25.52\right)$, Lantana camera ( $\mathrm{D}=1800 \mathrm{ha}^{-1}, \mathrm{~F}=66.67 \%$, IVI=23.90), Flueggea leucopyrus $\left(\mathrm{D}=1333.33 \mathrm{ha}^{-1}, \mathrm{~F}=50 \%, \mathrm{IVI}=19.0\right)$, 
302

Barleria glabra ( $\left.\mathrm{D}=1,066.67 \mathrm{ha}^{-1}, \mathrm{~F}=50 \%, \mathrm{IVI}=16.42\right)$, Canthium coromandelicum $\left(\mathrm{D}=1066.67 \mathrm{ha}^{-1}, \mathrm{~F}=33.33 \%\right.$, IVI=16.33), Coffea wightiana ( $\mathrm{D}=933.33 \mathrm{ha}^{-1}, \mathrm{~F}=33.33 \%$, $\mathrm{IVI}=14.80)$, Catunaregam spinosa $\left(\mathrm{D}=800 \mathrm{ha}^{-1}, \mathrm{~F}=16.67 \%\right.$, IVI $=15.62)$ and Tarenna asiatica $\left(\mathrm{D}=800 \mathrm{ha}^{-1}, \mathrm{~F}=33.33 \%\right.$, $\mathrm{IVI}=13.27$ ).

Herb layer: This forest type grasses are dominant, and ground cover is represented by Aristida adscensionis $\left(\mathrm{D}=14.83 \mathrm{ha}^{-1}, \mathrm{~F}=83.33 \%\right)$, Evolvulus alsinoides $(\mathrm{D}=12.75$ $\left.\mathrm{ha}^{-1}, \mathrm{~F}=75 \%\right)$, Justicia procumbens $\left(\mathrm{D}=11.75 \mathrm{ha}^{-1}\right.$, $\mathrm{F}=83.33 \%)$, Brachiaria ramosa $\left(\mathrm{D}=10.42 \mathrm{ha}^{-1}, \mathrm{~F}=16.67 \%\right)$, Dipteracanthus patulus $\left(\mathrm{D}=6.42 \mathrm{ha}^{-1}, \quad \mathrm{~F}=91.67 \%\right)$, Dipteracanthus prostratus $\left(\mathrm{D}=4.0 \mathrm{ha}^{-1}, \mathrm{~F}=66.67 \%\right)$, Sida cordifolia $\left(\mathrm{D}=3.75 \mathrm{ha}^{-1}, \mathrm{~F}=41.67 \%\right)$, Oropetium thomaeum $\left(\mathrm{D}=3.33 \mathrm{ha}^{-1}, \mathrm{~F}=8.33 \%\right)$, Aristida setacea $\left(\mathrm{D}=2.42 \mathrm{ha}^{-1}\right.$, $\mathrm{F}=33.33 \%)$ and Plectranthus caninus $\left(\mathrm{D}=1.83 \mathrm{ha}^{-1}\right.$, $\mathrm{F}=25 \%)$.

\section{Species diversity and concentration of dominance}

The species diversity, concentration of dominance of different forest types are depicted (Table 2). The highest concentration of dominance was recorded for HwkF $(0.05)$ followed by $\operatorname{RvF}(0.03)$ and for all other 8 forest types is 0.01 . The species diversity $(\mathrm{H})$ was recorded highest for CUTF (5.28) followed by STF (5.22) and the lowest for $\operatorname{HwkF}(3.00)$.

\section{Native, rarity and endemic species}

Of the recorded species Twelve (12) species are endemic to peninsular India (Nayar and Sastry, 1990; Ravikumar and Ved, 2000); remaining species are non natives and Twenty one (21) species were rare for Peninsular India. Among threatened and near threatened category Three (03) species are Endangered (EN), Two (02) species are Rare and Two (02) species are Vulnerable. CUTF and STF forest represents maximum numbers (19 each) of threatened species viz. Endemic, Endangered, Rare and Vulnerable. Other forest types signify less number of threatened species.

The biodiversity on earth provides a large number of services to humankind. Biodiversity not only helps in the regulations of soil, water but it also provides food and shelter for survival. Due to increase in human population, has resulted in demand of more and more biological resources (Daily, 1995; Singh, 2002). These resources are limited and for the sustainable exploitation of these resources we have to formulate some strategies. Such activities are impairing and destroying ecosystems. For conservation and management of these species in wild an attempt have been made to assess and identify the status of diversity in Junction of Eastern and Western Ghats. The assessment was done by using the quantitative and qualitative attributes. Tree density significantly contributes to the forest functional diversity, ecological processes and ecosystem services (Puttookame et al., 2015). Tree species richness in Bannerghata forests ranged from 9-41species (Verma et al., 2009). In Mudumalai Forest in India has 63 tree species (Condit et al., 2000) and in present study area 51 species which is less then Mudumalai but higher then Bannerghata Forests. The five most abundant families in DFD were Fabaceae (34 nos.), Acanthaceae (24 nos.), Poaceae (22 nos.), Euphorbiaceae (17 nos.) and Rubiaceae (16 nos.), while Panda et al. (2013) found Euphorbiaceae and Moraceae to be the most dominant families in the northern portion of Eastern ghats, in southern portion of Eastern ghats in Bannerghata Forests is dominant by families Fabaceae, Caesalpiniaceae and Rubiaceae (Puttookame et al., 2015; Gopalkrishna et al., 2015), Mimosaceae, Rubiaceae, Apocynaceae were the most dominant families in Piranmalai Forest (Pitchairamu et al., 2008), Euphorbiaceae and Rubiaceae were most dominant in Shervarayan hill (Kadavul and Parthasarthy, 1999).

\section{Conclusions}

Economic well being of human is directly connected to its surrounding biodiversity and is an essential ingredient of ecosystem function and its stability. The floristic diversity of Dharmapuri forests will help forest department to develop management plan for these tropical dry forests of Eastern Ghats. The quantitative biodiversity data of Eastern Ghats will be useful in forest management and conservation. In view of this study it shows the tree density in forests along with the rare and endemic species of the forest division. During our study period we have observed that all the forested area of this division was subjected to continuous biotic pressure resulting into rapid degradation. With the help of JFM concept these areas can slowly be restored for recouping the vegetation. Due to perpetual grazing as observed in many areas, the new seedlings and saplings of important species like bamboo, medicinal plants and other NTFP species are often subjected to continuous damage. Management of grazing is very important for the conservation of natural vegetation. This will help to increase in availability of biomass for fodder, fuelwood in forest areas. With the help of this studies it has been identified the specific localities of each of CR/EN/VL species for this division and these localities can be further monitored to know their population dynamics and based on this a special conservation plan can be made and it should also be included in the working plan for their conservation in its respective habitats. To accomplish the success, a nursery can be raised close to the well identified forest area and these CR/EN/VL plants can be grown there and shall later be transferred to the specific natural habitats.

Table 2. Species diversity in different forest types

\begin{tabular}{ccccccccccc}
\hline & CUTF & DDS & EuS & HwkF & RvF & SDDF & SDMDF & SDS & STF & STS \\
\hline Individuals & 196 & 92 & 71 & 20 & 34 & 133 & 142 & 112 & 185 & 167 \\
\hline Dominance 'D' & 0.01 & 0.01 & 0.01 & 0.05 & 0.03 & 0.01 & 0.01 & 0.01 & 0.01 & 0.01 \\
Shannon 'H' & 5.28 & 4.52 & 4.26 & 3.00 & 3.53 & 4.89 & 4.96 & 4.72 & 5.22 & 5.12 \\
\hline Simpson 'D' & 0.99 & 0.99 & 0.99 & 0.95 & 0.97 & 0.99 & 0.99 & 0.99 & 0.99 & 0.99 \\
\hline
\end{tabular}

CUTF: Carnatic umbrella thorn forest; DDS: Dry deciduous scrub forest; EuS: Euphorbia scrub forest; HwkF: Hardwickia forest; RvF: Riverain forest; SDDF: Southern tropical dry deciduous forest; SDMDF: Southern tropical dry moist mixed deciduous forest; SDS: Southern scrub forest; STF: Deccan thorn forest and STS: Deccan thorn scrub forest. 


\section{Acknowledgements}

Authors are thankful to Forest Department of Tamilnadu for funding the project "Status and Survey of Selected CR/EN/DD Taxa in Wild Dharmapuri Forest Division, Tamilnadu", under Tamilnadu Biodiversity and Greening Project (TBGP) scheme activity component 1.1.3.1. Authors are also geatful to Director FRLHT Bangaluru for his support and guidance. We are thankful to our colleagues S. Gokul and N. Dhatchanamoorthy who provided skill and support during data collection and also assisted in data entry. We are also grateful to N. Begum and $\mathrm{N}$. Balachandran for providing their help during in the office. We have to express out appreciation to the Mr.Sanjay K. Srivastava, Project Director \& Adl. PCCF; DFO, Dharmapuri and Forest staff for sharing their pearls of wisdom with us during the course of this research. We are also immensely grateful to Dr Manoj Kumar Sarkar, IFS, Adl. PCCF for his comments and support during the course of study.

\section{References}

Ahmedullah M, Nayar MP (1987). Endemic plants of Indian region. Botanical Survey of India, Calcutta.

Ansari AA (2008). Crotalaria L. in India. Bishen Singh Mahendra Pal Singh, DehraDun.

Balakrishnan, NP, Chakrabarty T (2007). The family Euphorbiaceae in India. Bishen Singh Mahendra Pal Singh, Dehra Dun.

Balvanera P,Pfisterer BA, Buchmann N, HeJS, Nakashizuka T, RaffaelliD, Schmid B (2006). Quantifying the evidence for biodiversity effects on ecosystem functioning and services. Ecology Letters 9:1146-1156.

Champion HG, Seth SK (1968). A revised survey of forest types of India. Government of India Press, Delhi, India.

Condit R, Ashton PS, Baker P, Bunyavejohewin S, Gunatileke S, Gunatilleke N, Hubbell SP, Foster RB, Itoh A, LaFrankie JV, Lee HS, Losos E, Manokaran N, Sukumar R, Yamakura T (2000). Spatial patterns in the distribution of tropical tree species. Science 288:1414 1418.

Curtis JT, McIntosh RP (1950). The interrelations of certain analytic and synthetic phytosociological characters. Ecology 31:434455.

Curtis JT (1959). The Vegetation of Wisconsin, an Ordination of Plant Communities. University Wisconsin Press, Madison. Wisconsin.

Daily CG (1995). Restoring value to the world's degraded lands. Science 269:350-354.

Gamble JS, Fischer ECE (1915-1939). Flora of the presidencey of Madras. Adlard and Son Ltd., London.

Gopalakrishna SP, Kaonga ML, Somashekar RK, Suresh HS, Suresh R (2015). Tree diversity in the tropical dry forest of Bannerghatta National Park in Eastern Ghats, Southern India. European Journal of Ecology 1(2):12-27.

Henry AN, Kumari GR, Chithra V (1987). Flora of Tamil Nadu, India Series 1: Analysis, Volume2. Botanical Survey of India, Coimbatore.

Henry AN, Chithra V, Balakrishana NP (1989). Flora of Tamil Nadu, India Series 1: Analysis, Volume 3. Botanical Survey of India, Coimbatore.

Hooker,JD (1872-1897). Flora of British India, Volumes 1-7.L. Reeve and Company, Ashford, Kent, U.K.
Hooper DU, Chapin FS, Ewwel JJ, Hector A, Inchausti P, Lavorel S, ... Wardle DA (2005). Effects of biodiversity on ecosystem functioning: A consensus of currentsknowledge. Ecological Monographs 75(1):3-35.

Hubbell SP, Foster RB (1992). Short-term dynamics of a neotropical forest: why ecological research matters to tropical conservation and management. Oikos 63:48-61.

Jagtap AP, Singh NP (1999). Fascicles of flora of India. Botanical Survey of India, Calcutta

Jayakumar S, Soosairaj S, Samy DIA, Britto JS (2002). Similarity analysis in two tropical dry evergreen forests in the Eastern Ghats of Tamil Nadu. Journal of Hill Research 15:4-11.

Kadavul K, Parthasarathy N (1999). Plant biodiversity and conservation of tropical semi-evergreen in the Shervarayan hills of Eastern Ghats, India. Biodiversity Conservation 8: 421-439.

Kaya Z, Raynal DJ (2001). Biodiversity and conservation of Turkish forests. Biological Conservation 97(2):131-141.

Matthew KM (1981-1984). The flora of the Tamil Nadu Carnatic, Volumes I-III. The Rapinat Herbarium, St. Joseph's College, Tiruchirapalli.

May RM,Stumpf MPH(2000). Species-area relationships in tropical forests. Science 290:2084-2086.

Myers N, Mittermeier RA, Mittermeier CG, da Fonseca GA, Kent J (2000). Biodiversity hotspots for conservation priorities. Nature 403:853-858.

Naeem S, Wright JP (2003). Disentangling biodiversity effects on ecosystem functioning: deriving solutions to a seemingly insurmountable problem. Ecology Letters 6:567-579.

Naidu MT, Kumar OA (2015). Tree species diversity in the Eastern Ghats of northern Andhra Pradesh, India.Journal of Threatened Taxa 7(8):7443-7459.

Nayar MP, Sastry ARK (eds.) (1987-1990). Red data book of Indian Plants, Volume I-III. Botanical Survey of India, Calcutta.

Nayar MP (1996). "Hot spots" of endemic plants of India, Nepal and Bhutan. Tropical Botanical Garden and Research Institute, Palode, Thiruvananthapuram.

Panda PC, Mahapatra AK, Acharya PK, Debata AK (2013) Plant diversity in tropical deciduous forests of Eastern Ghats, India: A landscape assessment. International Journal of Biodiversity Conservation 5(10), 625-639.

Pitchairamu C, Muthuchelian K, Siva (2008). Floristic inventory and quantitative vegetation analysis of tropical dry deciduous forest in Piranmalai forest, Eastern Ghats, Tamil Nadu, India. Ethnobotanical Leaflets 12:204-216.

Pragasan A, Parthasarathy N (2010). Landscape-level tree diversity assessment in tropical forests of southern Eastern Ghats, India. Flora 205(11):728-737.

Puttakame GS, Kaonga ML, Somashekar RK, Suresh HS, Suresh R(2015). Tree diversity in the tropical dry forest of Bannerghatta National Park in Eastern Ghats, Southern India. European Journal of Ecology 1(2):1227.

Ravikumar K, Ved DK (2000). 100 Red-list medicinal plants of conservation concern in Southern India. Foundation for Revitalisation ofLocal Health Traditions, Bangalore.

Sagar R, Raghubanshi AS, Singh JS (2003). Tree species composition, 
304

dispersion and diversity along a disturbance gradient in a dry tropical forest region of India. Forest Ecology and Management 186:61-71.

Sanjappa M (1992). Legumes of India. Bishen Singh Mahendra Pal Singh, DehraDun.

Shannon CE, Wiener W (1963). The mathematical theory of communication. University of Illinois Press, Urbana.

SimpsonEH(1949). Measurement of diversity. Nature 163(4148):688.

Singh SP (2002). Balancing the approaches of environmental conservation by considering ecosystem services as well as biodiversity. Current Science 82(11):1331-1335.

Sorensen T (1948). A method of establishing groups of equal amplitude in plant sociology based on similarity of species content. Dent Kong Dansk Vindensk(Copenhegen) 5:1-34.

Vajravelu E, Rathakrishnan NC (1967-1968). A contribution to the flora of Dharmapuri district, Madras State. Botanical Survey of India 9:31-48.
Varma S, Anand VD, Avinash KG, Nishant MS (2009). Ecology, conservation and management of the Asian elephant in Bannerghatta National Park, Southern India. A Rocha India/ANCF: Asian Elephant Ecology and Conservation Reference Series No.1. A Rocha India and Asian Nature Conservation Foundation, Bangalore.

Villaseñor JL, Maeda P, Rosell JA, Ortiz E (2007). Plant families as predictors of plant biodiversity in Mexico. Diversity and Distributions 13:871-876.

Wilson EO (1988). The current state of biological diversity. In: Wilson EO. and Peter FM (Eds). Biodiversity. National Academy Press, Washington DC,pp3-18. 
Appendix 1. Diversity of plants in the sample quadrats for various forest types in Dharmapuri forest division with reference to their threat status

List of species recapitulation in forest types of Dharmapuri Forest Division.

\begin{tabular}{ccccc}
\hline Sr. no. & Species Name & Habit & Families & $\begin{array}{c}\text { Status } \\
\text { Presens of species } \\
\text { in forest types }\end{array}$ \\
\hline 1 & Abrusprecatorius L. & C & Fabaceae & 7 \\
2 & Abutilon crispum (L.) Medik. & H & Malvaceae & $1,6,7$ \\
3 & Abutilon indicum (L.) Sweet & H & Malvaceae & 1 \\
4 & Acacia caesia (L.) Willd. & L & Mimosaceae & 5,7 \\
5 & $\begin{array}{c}\text { Acacia chundra } \\
\text { (Rottler) Willd. }\end{array}$ & T & Mimosaceae & $1,9,10$ \\
6 & $\begin{array}{c}\text { Acacia leucophloea } \\
\text { (Roxb.) Willd. }\end{array}$ & T & Mimosaceae & $1,2,7,9,10$ \\
7 & $\begin{array}{c}\text { Acacia pinnata Link } \\
8\end{array}$ & S & Mimosaceae & $1,7,9,10$ \\
& Acacia planifrons Wight $\&$ & T & Mimosaceae & $1,2,3,6,7,8,9,10$
\end{tabular}

$\begin{array}{cccccc}9 & \begin{array}{c}\text { Acalypha alnifolia } \\ \text { Klein ex Willd. }\end{array} & \text { H } & \text { Euphorbiaceae } & \text { Endemi } & 1,10 \\ 10 & \text { Acalypha fruticosa Forsk. } & \text { H } & \text { Euphorbiaceae } & 1,2,3,6,7,8,9,10 \\ 11 & \text { Acalypha indica L. } & \text { H } & \text { Euphorbiaceae } & 1,6 \\ 12 & \text { Acanthospermum hispidum } & \text { H } & \text { Asteraceae } & 10\end{array}$

$\begin{array}{ccccc}13 & \text { Achyranthes aspera L. } & \mathrm{H} & \text { Amaranthaceae } & 1,2,4,5,6,7,8 \\ 14 & \begin{array}{c}\text { Actiniopteris radiata } \\ \text { (Sw.) Link }\end{array} & \text { Ferns } & \text { Pteridaceae } & 1,2,6,9 \\ & & \end{array}$

$\begin{array}{cccccc}38 & \text { Azadirachta indica A.Juss. } & \text { T } & \text { Meliaceae } & 1,2,3,4,5,6,7,8,9,1 \\ 39 & \text { Azima tetracantha Lam. } & \text { S } & \text { Salvadoraceae } & 0 \\ 40 & \text { Barleria buxifolia L. } & \text { H } & \text { Acanthaceae } & 5,6 \\ 41 & \text { Barleria glabra Noronha } & \text { H } & \text { Acanthaceae } & 1,2,3,6,8,9 \\ 42 & \text { Barleria longiflora L.f. } & \text { H } & \text { Acanthaceae } & \text { Endemi } & 1,3,4,6,7,8,9 \\ & & & & c & \end{array}$

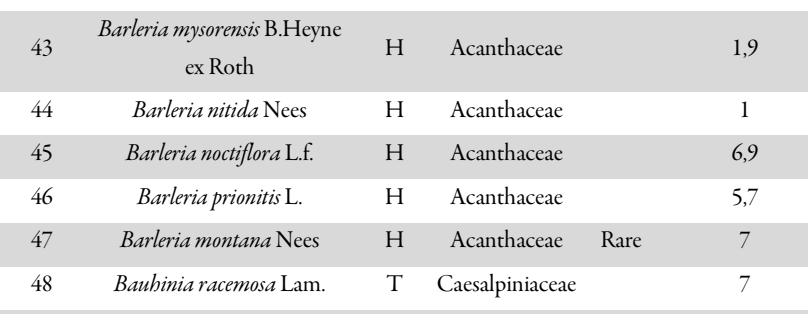

$\begin{array}{ccccc}49 & \begin{array}{c}\text { Benkara malabarica (Lam.) } \\ \text { Tirveng. }\end{array} & \text { S } & \text { Rubiaceae } & 6 \\ 50 & \text { Bidenspilosa L. } & \text { H } & \text { Asteraceae } & 9,10\end{array}$

Blepharis maderaspatensis (L.)
B.Heyne ex Roth H Acanthaceae $\quad 1,2,6,8,9,10$

52 Blepharis repens (Vahl) Roth H Acanthaceae 1,6,7,8,9

$53 \quad$ Boerhavia diffusa L. H Nyctaginaceae $\quad 1,2,6,8,9,10$

$54 \quad$ Borassusflabellifer $\mathrm{L} . \quad \mathrm{P} \quad$ Caesalpiniaceae $\quad 7$

55 Brachiariaramosa (L.) Stapf Grass Poaceae 1,2,3,6,8,9,10

56 Brachiaria remota (Retz.) Grass Poaceae $\quad 1,8,9$

$57 \begin{gathered}\text { Bulbostylis barbata (Rottb.) } \\ \text { C.B.Clarke }\end{gathered}$ Sedges $\quad$ Poaceae $2,6,9,10$

15 Adiantum lunulatum Burm.f. Ferns Pteridaceae 1,2,8,9

16 Aervalanata (L.) Juss. H Amaranthaceae $\quad 1,4,5,6$

$\begin{array}{ccccc}17 & \text { Ageratum conyzoides (L.) L. } & \text { H } & \text { Asteraceae } & 7 \\ 18 & \begin{array}{c}\text { Alangium salvifolium } \\ \text { (L.f.) Wangerin }\end{array} & \text { T } & \text { Alangiaceae } & 3,9,10\end{array}$

\begin{tabular}{|c|c|c|c|}
\hline 19 & $\begin{array}{c}\text { Albizia amara (Roxb.) } \\
\text { B.Boivin }\end{array}$ & Mimosaceae & $\begin{array}{c}1,2,3,4,5,6,7,8,9,1 \\
0\end{array}$ \\
\hline
\end{tabular}

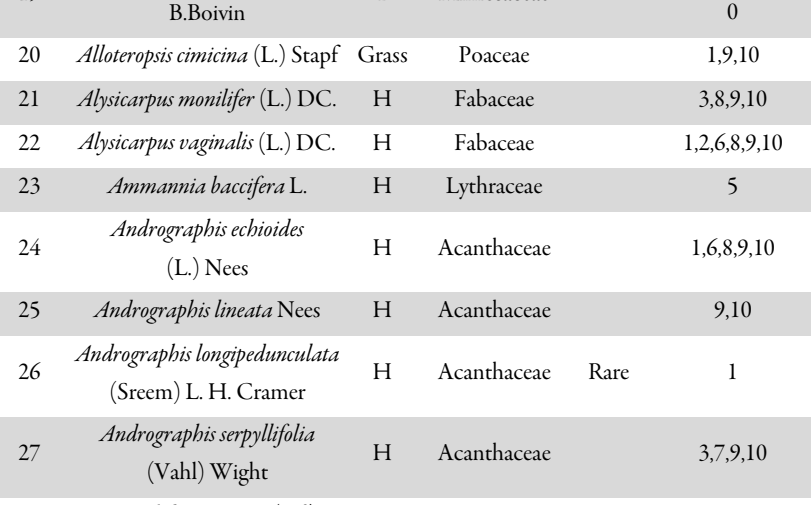

\begin{tabular}{|c|c|c|c|c|c|}
\hline 28 & $\begin{array}{c}\text { Anisochilus carnosus (L.f.) } \\
\text { Wall. }\end{array}$ & $\mathrm{H}$ & Lamiaceae & & 3,9 \\
\hline 29 & Anisomeles indica (L.) Kuntze & $\mathrm{H}$ & Lamiaceae & & 5 \\
\hline 30 & Annona squamosa $\mathrm{L}$. & UT & Annonaceae & & $1,3,6,10$ \\
\hline 31 & Apluda mutica $\mathrm{L}$. & Grass & Poaceae & & 1,10 \\
\hline 32 & $\begin{array}{c}\text { Argyreia elliptica Arn. ex } \\
\text { Choisy }\end{array}$ & $\mathrm{C}$ & $\begin{array}{c}\text { Convolvulacea } \\
\text { e }\end{array}$ & Rare & 7 \\
\hline 33 & Aristida adscensionis L. & Grass & Poaceae & & $1,6,9,10$ \\
\hline 34 & Aristida setacea Retz. & Grass & Poaceae & & $1,2,3,7,9,10$ \\
\hline 35 & Aristolochia indica $\mathrm{L}$. & $\mathrm{C}$ & $\begin{array}{c}\text { Aristolochiacea } \\
\text { e }\end{array}$ & & 2,10 \\
\hline 36 & Asparagus racemosus Willd. & $\mathrm{H}$ & Liliaceae & & $1,2,7,8,9$ \\
\hline 37 & Atalantia monophylla DC. & $\mathrm{T}$ & Rutaceae & & 7 \\
\hline
\end{tabular}

58 Buteamonosperma (Lam.) $\mathrm{T} \quad$ Fabaceae 2

59 Cadabafruticosa (L.) Druce $\quad \mathrm{S} \quad$ Capparaceae $\quad 1,7,10$

60 Cajanusscarabaeoides (L.) $\quad \mathrm{H} \quad$ Fabaceae $\quad 7,10$

$\begin{array}{lcccc}61 & \text { Cansjera rheedii Blanco } & \text { L } & \text { Opiliaceae } & 7 \\ 62 & \begin{array}{c}\text { Canthium coromandelicum } \\ \text { (Burm.f.) Alston }\end{array} & \text { S } & \text { Rubiaceae } & 2,3,6,7,8,9,10\end{array}$

\begin{tabular}{rccccc}
63 & Capparis divaricata Lam. & S & Capparaceae & EN & 9,10 \\
\hline 64 & Capparis grandis L.f. & T & Capparaceae & Rare & 7 \\
\hline 65 & Capparis sepiaria L. & S & Capparaceae & & $1,3,6,7,9,10$ \\
66 & Cappariszeylanica L. & L & Capparaceae & & $1,5,6,7,9,10$
\end{tabular}

67 Caralluma adscendens var.

Mayur.
Caralluma adscendens var.

68 fimbriata (Wall.) Gravely \& $\quad \mathrm{H} \quad$ Asclepiadaceae $\begin{gathered}\text { Endemi } \\ \text { c }\end{gathered}$ Mayur.

69 Caralluma umbellata Haw. H Asclepiadaceae 8

70 Cardiospermum canescens $\quad$ C $\quad$ Sapindaceae $\quad 1,2,3,6,7,8,10$

\begin{tabular}{|ccccc|}
\hline 71 & Carissa carandas $\mathrm{L}$. & S & Apocynaceae & 7 \\
\hline 72 & Carissa spinarum $\mathrm{L}$. & S & Apocynaceae & 7 \\
\hline 73 & Cassia absus L. & H & Caesalpiniaceae & $1,8,9$ \\
\hline 74 & Cassia auriculata L. & S & Caesalpiniaceae & $1,2,6,7,8,9,10$ \\
\hline 75 & Cassia fistula L. & T & Caesalpiniaceae & $1,8,9,10$ \\
\hline 76 & Cassia glauca Lam. & S & Caesalpiniaceae & 1,10 \\
77 & Cassia italica $($ Mill.) & H & Caesalpiniaceae & 1,9 \\
\hline
\end{tabular}


$\mathrm{xx}$

\begin{tabular}{|c|c|c|c|c|c|}
\hline 78 & $\begin{array}{c}\text { Cassia montana Naves \& } \\
\text { Villar }\end{array}$ & $S$ & Caesalpiniaceae & $\begin{array}{c}\text { Endemi } \\
\qquad \mathrm{c}\end{array}$ & $1,2,6,9,10$ \\
\hline 79 & Cassia occidentalis $\mathrm{L}$. & $\mathrm{H}$ & Caesalpiniaceae & & $1,7,10$ \\
\hline 80 & Cassia pumila Lam. & $\mathrm{H}$ & Caesalpiniaceae & & 8,10 \\
\hline 81 & Cassia siamea Lam. & $\mathrm{T}$ & Caesalpiniaceae & & $8,9,10$ \\
\hline 82 & Cassia tora $\mathrm{L}$. & $\mathrm{H}$ & Caesalpiniaceae & & 9,10 \\
\hline 83 & Cassine balae Kosterm. & $\mathrm{T}$ & Celstraceae & & 7 \\
\hline 84 & $\begin{array}{l}\text { Catunaregam spinosa } \\
\text { (Thunb.) Tirveng. }\end{array}$ & $S$ & Rubiaceae & & $1,2,3,6,7,8,9,10$ \\
\hline 85 & Celastrus paniculatus Willd. & $\mathrm{L}$ & Celstraceae & & 7 \\
\hline 86 & Celosia polygonoides Retz. & $\mathrm{H}$ & Amaranthaceae & & $1,4,6,9$ \\
\hline 87 & $\begin{array}{l}\text { Celtis philippensis var. wightii } \\
\text { (Planch.) Soepadmo }\end{array}$ & $\mathrm{T}$ & Ulmaceae & & 4 \\
\hline 88 & $\begin{array}{c}\text { Chlorophytum malabaricum } \\
\text { Baker }\end{array}$ & $\mathrm{H}$ & Liliaceae & Rare & 9 \\
\hline 89 & Chlorophytum sp. & $\mathrm{H}$ & Liliaceae & & $2,6,7,8,9,10$ \\
\hline 90 & Chloroxylon swietenia DC. & $\mathrm{T}$ & Flindersiaceae & $\mathrm{EN}$ & $1,2,6,7,8,9,10$ \\
\hline 91 & $\begin{array}{c}\text { Chromolaena odorata (L.) } \\
\text { R.M.King \& H.Rob. }\end{array}$ & $\mathrm{H}$ & Asteraceae & & $1,2,3,9,10$ \\
\hline 92 & $\begin{array}{c}\text { Chrysopogon fulvus (Spreng.) } \\
\text { Chiov. }\end{array}$ & Grass & Poaceae & & 7 \\
\hline 93 & $\begin{array}{c}\text { Cipadessa baccifera (Roth) } \\
\text { Miq. }\end{array}$ & $S$ & Meliaceae & & 2,10 \\
\hline 94 & $\begin{array}{l}\text { Cissampelos pareira var. hirsuta } \\
\text { (Buch.-Ham. ex DC.) } \\
\text { Forman }\end{array}$ & $\mathrm{C}$ & $\begin{array}{c}\text { Menispermacea } \\
\text { e }\end{array}$ & & 9 \\
\hline 95 & Cissus quadrangularis $\mathrm{L}$. & $\mathrm{L}$ & Vitaceae & & $1,2,3,4,6,7,8,9,10$ \\
\hline 96 & $\begin{array}{c}\text { Cleistanthus collinus (Roxb.) } \\
\text { Benth. ex Hook.f. }\end{array}$ & $\mathrm{T}$ & Euphorbiaceae & & $2,7,8,9$ \\
\hline 97 & $\begin{array}{c}\text { Cleome aspera J.Koenig ex } \\
\text { DC. }\end{array}$ & $\mathrm{H}$ & Cleomaceae & & $1,2,7,9,10$ \\
\hline 98 & Cleome felina L.f. & $\mathrm{H}$ & Cleomaceae & $\begin{array}{c}\text { Endemi } \\
\mathrm{c}\end{array}$ & 1 \\
\hline 99 & Cleome monophylla $\mathrm{L}$. & $\mathrm{H}$ & Cleomaceae & & 9 \\
\hline 100 & Cleome viscosa $\mathrm{L}$. & $\mathrm{H}$ & Cleomaceae & & $6,8,9$ \\
\hline 101 & Coccinia grandis (L.) Voigt & $\mathrm{C}$ & Cucurbitaceae & & 1,6 \\
\hline 102 & $\begin{array}{c}\text { Cocculus hirsutus (L.) } \\
\text { W.Theob. }\end{array}$ & $\mathrm{L}$ & $\begin{array}{c}\text { Menispermacea } \\
\text { e }\end{array}$ & & $1,2,3,4,5,6,7,8$ \\
\hline 103 & $\begin{array}{c}\text { Coffea wightiana Wall. ex } \\
\text { Wight \& Arn. }\end{array}$ & $S$ & Rubiaceae & & $1,3,6,7,8,10$ \\
\hline 104 & Combretum albidum G. Don & $\mathrm{L}$ & Combertaceae & & 1 \\
\hline 105 & $\begin{array}{l}\text { Commelina attenuata } \\
\text { K.D.Koenig ex Vahl }\end{array}$ & $\mathrm{H}$ & $\begin{array}{c}\text { Commelinacea } \\
\mathrm{e}\end{array}$ & & 7 \\
\hline 106 & Commelina benghalensis $\mathrm{L}$. & $\mathrm{H}$ & $\begin{array}{c}\text { Commelinacea } \\
\mathrm{e}\end{array}$ & & $1,6,7,8,9,10$ \\
\hline 107 & Commelina diffusa Burm.f. & $\mathrm{H}$ & $\begin{array}{c}\text { Commelinacea } \\
\mathrm{e}\end{array}$ & & $1,6,9,10$ \\
\hline 108 & Commelina paleata Hassk. & $\mathrm{H}$ & $\begin{array}{c}\text { Commelinacea } \\
\mathrm{e}\end{array}$ & & 1 \\
\hline 109 & $\begin{array}{c}\text { Commiphora berryi (Arn.) } \\
\text { Engl. }\end{array}$ & $S$ & Burseraceae & $\begin{array}{c}\text { Endemi } \\
\mathrm{c}\end{array}$ & 1,3 \\
\hline 110 & $\begin{array}{c}\text { Commiphora caudata (Wight } \\
\text { \& Arn.) Engl. }\end{array}$ & $S$ & Burseraceae & & 7 \\
\hline 111 & $\begin{array}{l}\text { Corallocarpus epigaeus } \\
\text { (Rottler) Hook.f. }\end{array}$ & $\mathrm{C}$ & Cucurbitaceae & & $1,3,6,8,10$ \\
\hline 112 & $\begin{array}{l}\text { Corbichonia decumbens } \\
\text { (Forssk.) Exell }\end{array}$ & $\mathrm{H}$ & Molluginaceae & & $1,6,7,8,10$ \\
\hline 113 & Corchorus aestuans $\mathrm{L}$. & $\mathrm{H}$ & Tiliaceae & & 1,3 \\
\hline
\end{tabular}

\begin{tabular}{|c|c|c|c|c|c|}
\hline 114 & Corchorus tridens $\mathrm{L}$. & $\mathrm{H}$ & Tiliaceae & & 1 \\
\hline 115 & Corchorus trilocularis $\mathrm{L}$. & $\mathrm{H}$ & Tiliaceae & & 1,10 \\
\hline 116 & Cordia monoica Roxb. & $S$ & Boraginaceae & Rare & 6,7 \\
\hline 117 & Crateva religiosa G.Forst. & $\mathrm{T}$ & Capparaceae & & 5 \\
\hline 118 & Crotalaria calycina Schrank & $\mathrm{H}$ & Fabaceae & Rare & \\
\hline 119 & $\begin{array}{c}\text { Crotalaria hebecarpa (DC.) } \\
\text { Rudd }\end{array}$ & $\mathrm{H}$ & Fabaceae & Rare & $1,3,8,9$ \\
\hline 120 & Crotalaria medicaginea Lam. & $\mathrm{H}$ & Fabaceae & & $1,6,7,8,9,10$ \\
\hline 121 & Croton bonplandianus Baill. & $\mathrm{H}$ & Euphorbiaceae & & 1,9 \\
\hline 122 & Cryptolepis grandiflora Wight & $\mathrm{C}$ & Asclepiadaceae & & $1,2,7,9$ \\
\hline 123 & Curculigo orchioides Gaertn. & $\mathrm{H}$ & Hypoxidaceae & & $3,6,7,9,10$ \\
\hline 124 & Cyanotis cristata (L.) D.Don & $\mathrm{H}$ & $\begin{array}{c}\text { Commelinacea } \\
\mathrm{e}\end{array}$ & & $1,2,6,7,9,10$ \\
\hline 125 & $\begin{array}{l}\text { Cyanotis tuberosa (Roxb.) } \\
\text { Schult. \& Schult.f. }\end{array}$ & $\mathrm{H}$ & $\begin{array}{c}\text { Commelinacea } \\
\text { e }\end{array}$ & & $1,2,3,6,7,8,9,10$ \\
\hline 126 & $\begin{array}{l}\text { Cymbopogon flexuosus (Nees } \\
\text { ex Steud.) W.Watson }\end{array}$ & Grass & Poaceae & & $1,9,10$ \\
\hline 127 & Cynodon dactylon (L.) Pers. & Grass & Poaceae & & 1,3 \\
\hline 128 & $\begin{array}{c}\text { Dactyloctenium aegyptium (L.) } \\
\text { Willd. }\end{array}$ & Grass & Poaceae & & 6,10 \\
\hline 129 & Dalbergia paniculata Roxb. & $\mathrm{T}$ & Fabaceae & & 7,10 \\
\hline 130 & $\begin{array}{c}\text { Dendrophthoe falcata (L.f.) } \\
\text { Ettingsh. }\end{array}$ & Grass & Loranthaceae & & 8 \\
\hline 131 & $\begin{array}{c}\text { Desmodium gangeticum }(\mathrm{L} .) \\
\text { DC. }\end{array}$ & $\mathrm{H}$ & Fabaceae & & 1 \\
\hline 132 & $\begin{array}{c}\text { Desmodium triflorum (L.) } \\
\text { DC. }\end{array}$ & Grass & Fabaceae & & $7,9,10$ \\
\hline 133 & $\begin{array}{c}\text { Dichrostachys cinerea (L.) } \\
\text { Wight \& Arn. }\end{array}$ & UT & Mimosaceae & & $3,7,10$ \\
\hline 134 & $\begin{array}{l}\text { Digitaria bicornis (Lam.) } \\
\text { Roem. \& Schult. }\end{array}$ & Grass & Fabaceae & & $6,7,8,9,10$ \\
\hline 135 & $\begin{array}{c}\text { Digitaria ciliaris (Retz.) } \\
\text { Koeler }\end{array}$ & Grass & Fabaceae & & $1,2,6,9,10$ \\
\hline 136 & Dioscorea oppositifolia L. & $\mathrm{C}$ & Dioscoreaceae & & 4 \\
\hline 137 & Dioscorea pentaphylla $\mathrm{L}$. & $\mathrm{C}$ & Dioscoreaceae & & 1,7 \\
\hline 138 & Diospyrosferrea (Willd.) Bakh. & $\mathrm{T}$ & Ebenaceae & & 7 \\
\hline 139 & $\begin{array}{l}\text { Diospyros malabarica (Desr.) } \\
\text { Kostel. }\end{array}$ & $\mathrm{T}$ & Ebenaceae & & 9 \\
\hline 140 & Diospyros montana Roxb. & $\mathrm{T}$ & Ebenaceae & & $1,3,6,7,8,9,10$ \\
\hline 141 & $\begin{array}{c}\text { Dipcadi madrasicum E.Barnes } \\
\text { \& C.E.C.Fisch. }\end{array}$ & $\mathrm{H}$ & Liliaceae & & 9,10 \\
\hline 142 & $\begin{array}{c}\text { Diplocyclospalmatus (L.) } \\
\text { C.Jeffrey }\end{array}$ & $\mathrm{H}$ & Liliaceae & & 6,8 \\
\hline 143 & $\begin{array}{c}\text { Dipteracanthus patulus (Jacq.) } \\
\text { Nees }\end{array}$ & $\mathrm{H}$ & Acanthaceae & & $1,2,3,6,7,9$ \\
\hline 144 & $\begin{array}{c}\text { Dipteracanthus prostratus } \\
\text { (Poir.) Nees }\end{array}$ & $\mathrm{H}$ & Acanthaceae & & $1,2,3,6,8,9,10$ \\
\hline 145 & Dodonaea viscosa (L.) Jacq. & S & Sapindaceae & & $1,2,6,7,8,9,10$ \\
\hline 146 & $\begin{array}{l}\text { Dregea volubilis (L.f.) Benth. } \\
\text { ex Hook.f. }\end{array}$ & $\mathrm{C}$ & Asclepiadaceae & & $7,9,10$ \\
\hline 147 & $\begin{array}{l}\text { Drypetes sepiaria (Wight \& } \\
\text { Arn.) Pax \& K.Hoffm. }\end{array}$ & $\mathrm{T}$ & Euphorbiaceae & & 7,9 \\
\hline 148 & Ehretia microphylla Lam. & S & Boraginaceae & & $3,7,9$ \\
\hline 149 & Elytraria acaulis (L.f.) Lindau & $\mathrm{H}$ & Acanthaceae & & $6,9,10$ \\
\hline 150 & $\begin{array}{c}\text { Emilia sonchifolia (L.) DC. ex } \\
\text { DC. }\end{array}$ & $\mathrm{H}$ & Asteraceae & & 9 \\
\hline 151 & $\begin{array}{c}\text { Endostemon viscosus (Roth) } \\
\text { M.R.Ashby }\end{array}$ & $\mathrm{H}$ & Lamiaceae & & 9,10 \\
\hline
\end{tabular}




\begin{tabular}{|c|c|c|c|c|c|}
\hline 152 & $\begin{array}{c}\text { Eragrostiella bifaria (Vahl) } \\
\text { Bor }\end{array}$ & Grass & Poaceae & & $1,5,6,8,10$ \\
\hline 153 & $\begin{array}{c}\text { Eragrostis gangetica (Roxb.) } \\
\text { Steud. }\end{array}$ & Grass & Poaceae & & 9 \\
\hline 154 & $\begin{array}{l}\text { Eragrostis tenella (L.) P.Beauv. } \\
\quad \text { ex Roem. \& Schult. }\end{array}$ & Grass & Poaceae & & 7 \\
\hline 155 & $\begin{array}{c}\text { Erythroxylum monogynum } \\
\text { Roxb. }\end{array}$ & UT & $\begin{array}{c}\text { Erythroxylacea } \\
\mathrm{e}\end{array}$ & & $1,2,5,7,9,10$ \\
\hline 156 & Euphorbia antiquorum $\mathrm{L}$. & UT & Euphorbiaceae & & $1,2,3,6,7,8,9,10$ \\
\hline 157 & Euphorbia hirta L. & $\mathrm{H}$ & Euphorbiaceae & & $1,2,6,9,10$ \\
\hline 158 & $\begin{array}{c}\text { Euphorbia tortilis Rottler ex } \\
\text { Ainslie }\end{array}$ & UT & Euphorbiaceae & & 1,9 \\
\hline 159 & Evolvulus alsinoides (L.) L. & $\mathrm{H}$ & $\begin{array}{c}\text { Convolvulacea } \\
\text { e }\end{array}$ & & $1,2,3,6,7,8,9,10$ \\
\hline 160 & Ficus mollis Vahl & $\mathrm{T}$ & Moraceae & & 1 \\
\hline 161 & $\begin{array}{l}\text { Fimbristylis dichotoma (L.) } \\
\text { Vahl }\end{array}$ & Sedges & Cyperaceae & & 7,10 \\
\hline 162 & $\begin{array}{c}\text { Fimbristylis ovata (Burm.f.) } \\
\text { J.Kern }\end{array}$ & Sedges & Cyperaceae & & $1,2,3,7,8,9,10$ \\
\hline 163 & $\begin{array}{c}\text { Flacourtia indica (Burm.f.) } \\
\text { Merr. }\end{array}$ & $S$ & Flacourtiaceae & & $1,2,6,8,9,10$ \\
\hline 164 & Flueggea leucopyrus Willd. & $S$ & Euphorbiaceae & & $1,2,3,5,6,7,8,9,10$ \\
\hline 165 & $\begin{array}{c}\text { Galactia tenuiflora (Willd.) } \\
\text { Wight \& Arn. }\end{array}$ & $\mathrm{H}$ & Fabaceae & & 2,7 \\
\hline 166 & Gardenia resinifera Roth & $S$ & Rubiaceae & Rare & 9 \\
\hline 167 & Gisekia pharnaceoides L. & $\mathrm{H}$ & Molluginaceae & & 6 \\
\hline 168 & Gloriosa superba L. & $\mathrm{H}$ & Liliaceae & EN & $1,6,7,8,9,10$ \\
\hline 169 & $\begin{array}{c}\text { Glossocardia bosvallia (L.f.) } \\
\text { DC. }\end{array}$ & $\mathrm{H}$ & Asteraceae & & $1,2,8,9,10$ \\
\hline 170 & Gmelina asiatica L. & S & Verbenaceae & & $1,7,8,9,10$ \\
\hline 171 & Grewia bracteata Roth & S & Tiliaceae & Rare & 9 \\
\hline 172 & Grewia flavescens Juss. & S & Tiliaceae & & 1,7 \\
\hline 173 & Grewia hirsuta Vahl & S & Tiliaceae & & 1 \\
\hline 174 & Grewia orientalis L. & S & Tiliaceae & & $1,2,6,8,9,10$ \\
\hline 175 & Grewia rhamnifolia Burret & $S$ & Tiliaceae & & 1 \\
\hline 176 & Grewia tenax (Forssk.) Fiori & S & Tiliaceae & Rare & $1,6,7$ \\
\hline 177 & Grewia villosa Willd. & S & Tiliaceae & & 8 \\
\hline 178 & $\begin{array}{c}\text { Gymnema sylvestre (Retz.) } \\
\text { R.Br. ex Sm. }\end{array}$ & $\mathrm{C}$ & Asclepiadaceae & & $1,7,8,9,10$ \\
\hline 179 & $\begin{array}{c}\text { Gymnosporia ovata Wall. ex } \\
\text { M. Lawson }\end{array}$ & $S$ & Celstraceae & & 7 \\
\hline 180 & Gyrocarpus americanus Jacq. & $\mathrm{T}$ & Hernandiaceae & & $1,4,7$ \\
\hline 181 & Hardwickia binata Roxb. & $\mathrm{T}$ & Caesalpiniaceae & $\begin{array}{c}\text { Endemi } \\
c\end{array}$ & 4 \\
\hline 182 & Hedyotis corymbosa (L.) Lam. & $\mathrm{H}$ & Rubiaceae & & 6,10 \\
\hline 183 & $\begin{array}{c}\text { Hedyotispuberula (G.Don) } \\
\text { R.Br. ex Arn. }\end{array}$ & $\mathrm{H}$ & Boraginaceae & & $1,3,6,8,9,10$ \\
\hline 184 & Heliotropium bracteatum R.Br. & $\mathrm{H}$ & Boraginaceae & & 1 \\
\hline 185 & $\begin{array}{l}\text { Heliotropium marifolium } \\
\text { J.Koenig ex Retz. }\end{array}$ & $\mathrm{H}$ & Boraginaceae & & $6,8,9,10$ \\
\hline 186 & $\begin{array}{l}\text { Hemidesmus indicus (L.) R. Br. } \\
\text { ex Schult. }\end{array}$ & $\mathrm{C}$ & Asclepiadaceae & & $1,2,7,8,10$ \\
\hline 187 & $\begin{array}{l}\text { Heteropogon contortus (L.) } \\
\text { P.Beauv. ex Roem. \& Schult. }\end{array}$ & $\mathrm{H}$ & Poaceae & & $1,9,10$ \\
\hline 188 & Hibiscus hirtus $\mathrm{L}$. & $\mathrm{H}$ & Malvaceae & & 1 \\
\hline 189 & $\begin{array}{c}\text { Hibiscus lobatus (Murray) } \\
\text { Kuntze }\end{array}$ & $\mathrm{H}$ & Malvaceae & & $1,3,9,10$ \\
\hline
\end{tabular}

\begin{tabular}{|c|c|c|c|c|c|}
\hline 190 & Hibiscus micranthus L.f. & $\mathrm{H}$ & Malvaceae & & $1,2,6,8,9,10$ \\
\hline 191 & Holoptelea integrifolia Planch. & $\mathrm{T}$ & Ulmaceae & & $1,3,4,6,7,9,10$ \\
\hline 192 & $\begin{array}{c}\text { Hybanthus enneaspermus (L.) } \\
\text { F.Muell. }\end{array}$ & $\mathrm{H}$ & Violaceae & & $3,6,7$ \\
\hline 193 & Hyptis suaveolens (L.) Poit. & $\mathrm{H}$ & Lamiaceae & & 10 \\
\hline 194 & $\begin{array}{c}\text { Ichnocarpus frutescens (L.) } \\
\text { W.T.Aiton }\end{array}$ & $\mathrm{C}$ & Apocynaceae & & 2,9 \\
\hline 195 & $\begin{array}{c}\text { Indigofera colutea (Burm.f.) } \\
\text { Merr. }\end{array}$ & $\mathrm{H}$ & Fabaceae & & 1 \\
\hline 196 & Indigofera glabra $\mathrm{L}$. & $\mathrm{H}$ & Fabaceae & Rare & 1 \\
\hline 197 & Indigofera linnaei $\mathrm{Ali}$ & $\mathrm{H}$ & Fabaceae & & $1,2,7,8,9,10$ \\
\hline 198 & Indigofera tinctoria $\mathrm{L}$. & $\mathrm{H}$ & Fabaceae & & 6,9 \\
\hline 199 & Indigofera trifoliata $\mathrm{L}$. & $\mathrm{H}$ & Fabaceae & $\begin{array}{c}\text { Endemi } \\
c\end{array}$ & $1,6,8,9,10$ \\
\hline 200 & $\begin{array}{l}\text { Indigofera trita subsp. scabra } \\
\text { (Roth) De Kort \& G.Thijsse }\end{array}$ & $\mathrm{H}$ & Fabaceae & Rare & 1 \\
\hline 201 & $\begin{array}{c}\text { Ipomoea obscura (L.) Ker } \\
\text { Gawl. }\end{array}$ & $\mathrm{H}$ & $\begin{array}{c}\text { Convolvulacea } \\
\mathrm{e}\end{array}$ & & 1,7 \\
\hline 202 & $\begin{array}{c}\text { Ipomoea sepiaria Koenig ex } \\
\text { Roxb. }\end{array}$ & $\mathrm{C}$ & $\begin{array}{c}\text { Convolvulacea } \\
\mathrm{e}\end{array}$ & & 1,6 \\
\hline
\end{tabular}

\begin{tabular}{|ccccc}
203 & $\begin{array}{c}\text { Ipomoea staphylina } \text { Roem. \& } \\
\text { Schult. }\end{array}$ & C & $\begin{array}{c}\text { Convolvulacea } \\
\text { e }\end{array}$ & $1,2,3,6,8,9,10$ \\
\hline 204 & $\begin{array}{c}\text { Jasminum angustifolium } \text { (L.) } \\
\text { Willd. }\end{array}$ & C & Oleaceae & $1,2,6,7,8,9,10$ \\
& $\begin{array}{c}\text { Jasminum auriculatum } \text { Vahl } \\
205\end{array}$ & C & Oleaceae & $1,7,10$
\end{tabular}

\begin{tabular}{|ccccc}
205 & Jasminum auriculatum Vahl & C & Oleaceae & $1,7,10$ \\
\hline 206 & Jatropha gossypiifolia L. & S & Euphorbiaceae & $1,2,3,5,6,7,8,9,10$ \\
207 & Justicia glauca Rottler & H & Acanthaceae & $1,2,6,7,8,9,10$ \\
\hline 208 & Justicia procumbens L. & H & Acanthaceae & $1,2,3,6,8,9,10$ \\
209 & Justicia prostrata Gamble & H & Acanthaceae & $1,3,6,8,9,10$ \\
210 & Justicia tranquebariensis L.f. & H & Acanthaceae & $1,6,9,10$ \\
\hline
\end{tabular}

\begin{tabular}{|c|c|c|c|c|}
\hline 211 & $\begin{array}{c}\text { Kohautia aspera (B.Heyne ex } \\
\text { Roth) Bremek. }\end{array}$ & $\mathrm{H}$ & Rubiaceae & 1 \\
\hline 212 & Kyllinga monocephala Rottb. & $\mathrm{H}$ & Cyperaceae & 1 \\
\hline 213 & Kyllinga triceps $\mathrm{Sw}$. & $\mathrm{H}$ & Cyperaceae & $1,6,9,10$ \\
\hline 214 & Lantana camara $\mathrm{L}$. & S & Verbenaceae & $1,2,3,6,7,8,9,10$ \\
\hline 215 & Lantana veronicifolia Hayek & $S$ & Verbenaceae & 1,6 \\
\hline 216 & Leonotis nepetifolia (L.) R.Br. & $\mathrm{H}$ & Lamiaceae & 5,6 \\
\hline 217 & Lepidagathis cristata Willd. & $\mathrm{H}$ & Acanthaceae & 9 \\
\hline 218 & Leucas aspera (Willd.) Link & $\mathrm{H}$ & Lamiaceae & $1,6,10$ \\
\hline 219 & Leucas biflora (Vahl) Sm. & $\mathrm{H}$ & Lamiaceae & 10 \\
\hline 220 & Leucas indica (L.) Sm. & $\mathrm{H}$ & Lamiaceae & 9,10 \\
\hline 221 & Limonia acidissima Groff & $\mathrm{T}$ & Rutaceae & 7 \\
\hline 222 & $\begin{array}{c}\text { Maerua oblongifolia (Forssk.) } \\
\text { A.Rich. }\end{array}$ & $\mathrm{L}$ & Capparaceae & 9 \\
\hline
\end{tabular}

\begin{tabular}{cccccc}
223 & $\begin{array}{c}\text { Mariscus clarkei Turrill ex } \\
\text { Craib }\end{array}$ & H & Cyperaceae & $\begin{array}{c}\text { Endemi } \\
\text { c }\end{array}$ & $1,2,9,10$ \\
\hline 224 & Martynia annua L. & H & Martyniaccae & \\
225 & Medicago sativa L. & H & Fabaceae & 2 \\
\hline 226 & $\begin{array}{c}\text { Melhania incana B.Heyne ex } \\
\text { Wall. }\end{array}$ & H & Sterculiaceae & 9 \\
& & & $1,2,6$
\end{tabular}

\begin{tabular}{|ccccc}
\hline 227 & $\begin{array}{c}\text { Merremia tridentata }(\mathrm{L} .) \\
\text { Hallier f. }\end{array}$ & H & $\begin{array}{c}\text { Convolvulacea } \\
\text { e }\end{array}$ & $3,9,10$ \\
\hline 228 & Mimosa pudica L. & H & Mimosaceae & $8,9,10$ \\
\hline 229 & Mitracarpus hirtus (L.) DC. & H & Rubiaceae & $1,7,9,10$ \\
\hline 230 & Mollugo cerviana (L.) Ser. & H & Molluginaceae & 6 \\
\hline 231 & Mollugo nudicaulis Lam. & H & Molluginaceae & $2,3,6,7,8,9,10$ \\
\hline 232 & Mollugo oppositifolia L. & H & Molluginaceae & $2,8,10$
\end{tabular}




\begin{tabular}{|c|c|c|c|c|c|}
\hline & & & & & \\
\hline 233 & Mollugo pentaphylla $\mathrm{L}$. & $\mathrm{H}$ & Molluginaceae & & $1,2,3,5,6,9,10$ \\
\hline 234 & Morinda coreia Buch.-Ham. & $\mathrm{T}$ & Rubiaceae & & 2,9 \\
\hline 235 & Ocimum americanum $\mathrm{L}$. & $\mathrm{H}$ & Lamiaceae & & $1,6,8,9$ \\
\hline 236 & Ocimum tenuiflorum $\mathrm{L}$. & $\mathrm{H}$ & Lamiaceae & & $1,2,6,8,9$ \\
\hline 237 & $\begin{array}{c}\text { Oplismenus compositus (L.) } \\
\text { P.Beauv. }\end{array}$ & $\mathrm{H}$ & Poaceae & & 1,7 \\
\hline 238 & $\begin{array}{c}\text { Opuntia dillenii (Ker Gawl.) } \\
\text { Haw. }\end{array}$ & S & Cactaceae & & $1,2,3,6,7,9$ \\
\hline 239 & $\begin{array}{c}\text { Oropetium thomaeum (L.f.) } \\
\text { Trin. }\end{array}$ & Grass & Poaceae & & $1,2,6,9,10$ \\
\hline 240 & Orthosiphon glabratus Benth. & $\mathrm{H}$ & Lamiaceae & & $1,6,7,8,9,10$ \\
\hline 241 & $\begin{array}{l}\text { Orthosiphon thymiflorus } \\
\text { (Roth) Sleesen }\end{array}$ & $\mathrm{H}$ & Lamiaceae & & 7,8 \\
\hline 242 & Oxalis corniculata $\mathrm{L}$. & $\mathrm{H}$ & Oxalidaceae & & 1,10 \\
\hline 243 & Pachygone ovata (Poir.) Diels & $\mathrm{L}$ & $\begin{array}{c}\text { Menispermacea } \\
\text { e }\end{array}$ & & $1,7,8,9$ \\
\hline 244 & Panicum sp. & Grass & Poaceae & & 6 \\
\hline 245 & Parthenium hysterophorus $\mathrm{L}$. & $\mathrm{H}$ & Asteraceae & & 1 \\
\hline 246 & Passiflora foetida $\mathrm{L}$. & $\mathrm{C}$ & Passifloraceae & & $1,6,8,9,10$ \\
\hline 247 & Pavetta indica $\mathrm{L}$. & $S$ & Rubiaceae & & 1,7 \\
\hline 248 & Pavonia odorata Willd. & $\mathrm{H}$ & Malvaceae & & $1,2,6,7,8,9,10$ \\
\hline 249 & $\begin{array}{c}\text { Pavonia procumbens (Wight } \\
\text { \& Arn.) Walp. }\end{array}$ & $\mathrm{H}$ & Malvaceae & & 1 \\
\hline 250 & Pavonia zeylanica (L.) Cav. & $\mathrm{H}$ & Malvaceae & & $1,2,6,9$ \\
\hline 251 & Pedalium murex $\mathrm{L}$. & $\mathrm{H}$ & Pedaliaceae & & 6 \\
\hline 252 & $\begin{array}{c}\text { Pergularia daemia (Forssk.) } \\
\text { Chiov. }\end{array}$ & $\mathrm{C}$ & Asclepiadaceae & & $1,8,10$ \\
\hline 253 & $\begin{array}{l}\text { Peristrophe bicalyculata (Retz.) } \\
\text { Nees }\end{array}$ & $\mathrm{H}$ & Acanthaceae & & 1 \\
\hline 254 & Phoenix pusilla Gaertn. & $S$ & Areaceae & & $8,9,10$ \\
\hline 255 & Phoenix sylvestris (L.) Roxb. & $\mathrm{P}$ & Arecaceae & & 9 \\
\hline 256 & $\begin{array}{l}\text { Phyllanthus amarus } \\
\text { Schumach. \& Thonn. }\end{array}$ & $\mathrm{H}$ & Euphorbiaceae & & $1,2,3,2,6,7,8,9,10$ \\
\hline 257 & Phyllanthus maderaspatensis $\mathrm{L}$. & $\mathrm{H}$ & Euphorbiaceae & & $1,6,8,9,10$ \\
\hline 258 & Phyllanthus polyphyllus Willd. & S & Euphorbiaceae & & 7 \\
\hline 259 & Phyllanthus virgatus G.Forst. & $\mathrm{H}$ & Euphorbiaceae & & $1,2,3,2,7,8,9,10$ \\
\hline 260 & Physalis angulata $\mathrm{L}$. & $\mathrm{H}$ & Solanaceae & & 8 \\
\hline 261 & Plectranthus caninus Roth. & $\mathrm{H}$ & Lamiaceae & & 1,9 \\
\hline 262 & Plumbago zeylanica L. & $\mathrm{H}$ & $\begin{array}{c}\text { Plumbaginacea } \\
\mathrm{e}\end{array}$ & & 1 \\
\hline 263 & $\begin{array}{l}\text { Polyalthia cerasoides (Roxb.) } \\
\text { Bedd. }\end{array}$ & $\mathrm{T}$ & Annonaceae & & 8 \\
\hline 264 & $\begin{array}{c}\text { Polycarpaea corymbosa }(\mathrm{L} .) \\
\text { Lam. }\end{array}$ & $\mathrm{H}$ & $\begin{array}{c}\text { Caryophyllacea } \\
\text { e }\end{array}$ & & $6,8,9$ \\
\hline 265 & $\begin{array}{c}\text { Polycarpaea corymbosa (L.) } \\
\text { Lam. var. longipetala S.R. } \\
\text { Sriniv. \& Narasimh. }\end{array}$ & $\mathrm{H}$ & $\begin{array}{c}\text { Caryophyllacea } \\
\text { e }\end{array}$ & $\begin{array}{c}\text { Endemi } \\
\text { c }\end{array}$ & 6 \\
\hline 266 & Polygala chinensis L. & $\mathrm{H}$ & Polygalaceae & & $1,2,3,5,6,7,8,9,10$ \\
\hline 267 & Polygala javana DC. & $\mathrm{H}$ & Polygalaceae & & 10 \\
\hline 268 & Polygala sibirica L. & $\mathrm{H}$ & Polygalaceae & Rare & 1,9 \\
\hline 269 & Pongamia pinnata (L.) Pierre & $\mathrm{T}$ & Fabaceae & & $1,4,5,7,8,9,10$ \\
\hline 270 & Portulaca tuberosa Roxb. & $\mathrm{H}$ & Portulacaceae & & $1,6,7$ \\
\hline 271 & Premna latifolia Roxb. & $S$ & Verbenaceae & & 3,7 \\
\hline 272 & Premna tomentosa Willd. & $\mathrm{T}$ & Verbenaceae & & 2,9 \\
\hline 273 & Prosopis juliflora (Sw.) DC. & $\mathrm{T}$ & Mimosaceae & & 1,5 \\
\hline 274 & $\begin{array}{c}\text { Pseudarthria viscida (L.) } \\
\text { Wight \& Arn. }\end{array}$ & $\mathrm{H}$ & Fabaceae & NT & $2,3,2,7$ \\
\hline
\end{tabular}

\begin{tabular}{|c|c|c|c|c|c|}
\hline 275 & Psilotrichum nudum Wight & $\mathrm{H}$ & Amaranthaceae & & $1,7,9$ \\
\hline 276 & Psydrax dicoccos Gaertn. & UT & Rubiaceae & $\mathrm{VN}$ & $1,7,8,9,10$ \\
\hline 277 & $\begin{array}{l}\text { Pterolobium hexapetalum } \\
\text { (Roth) Santapau \& Wagh }\end{array}$ & $\mathrm{L}$ & Caesalpiniaceae & & $1,2,5,6,7,8,9,10$ \\
\hline 278 & Pupalia lappacea (L.) Juss. & $\mathrm{H}$ & Amaranthaceae & & 1 \\
\hline 279 & $\begin{array}{l}\text { Pupalia lappacea var. velutina } \\
\text { (Moq.) Hook.f. }\end{array}$ & $\mathrm{H}$ & Amaranthaceae & Rare & $1,6,9,10$ \\
\hline 280 & $\begin{array}{c}\text { Rhus mysurensis B. Heyne ex } \\
\text { Wight \& Arn. }\end{array}$ & $\mathrm{L}$ & Anacardiaceae & & 7,9 \\
\hline 281 & $\begin{array}{c}\text { Rhynchosia aurea (Willd.) } \\
\text { DC. }\end{array}$ & $\mathrm{H}$ & Fabaceae & Rare & 9,10 \\
\hline 282 & Rhynchosia cana (Willd.) DC. & $\mathrm{H}$ & Fabaceae & & 9 \\
\hline 283 & Rhynchosia minima (L.) DC. & $\mathrm{H}$ & Fabaceae & & 3,9 \\
\hline 284 & Riccia sp. & Moss & Ricciaceae & & $1,2,6,7,10$ \\
\hline 285 & Richardia scabra L. & $\mathrm{H}$ & Rubiaceae & & 10 \\
\hline 286 & $\begin{array}{c}\text { Rivea hypocrateriformis } \\
\text { Choisy }\end{array}$ & $\mathrm{C}$ & $\begin{array}{c}\text { Convolvulacea } \\
\text { e }\end{array}$ & & 10 \\
\hline 287 & $\begin{array}{l}\text { Rottboellia cochinchinensis } \\
\text { (Lour.) Clayton }\end{array}$ & Grass & Poaceae & & 1 \\
\hline 288 & Sageretia parviflora G.Don & $\mathrm{L}$ & Rhamnaceae & & 10 \\
\hline 289 & $\begin{array}{c}\text { Sansevieria roxburghiana } \\
\text { Schult. \& Schult.f. }\end{array}$ & $\mathrm{H}$ & Agavaceae & & 7,9 \\
\hline 290 & Santalum album $\mathrm{L}$. & $\mathrm{T}$ & Santalaceae & & 10 \\
\hline 291 & Sapindus emarginatus Vahl & $\mathrm{T}$ & Sapindaceae & $\mathrm{VN}$ & $4,5,7$ \\
\hline 292 & $\begin{array}{c}\text { Sarcostemma acidum (Roxb.) } \\
\text { Voigt }\end{array}$ & $\mathrm{C}$ & Asclepiadaceae & & $1,7,10$ \\
\hline 293 & $\begin{array}{c}\text { Sarcostemma secamone (L.) } \\
\text { Bennett }\end{array}$ & $\mathrm{C}$ & Asclepiadaceae & & 9 \\
\hline 294 & $\begin{array}{c}\text { Scilla hyacinthina (Roth) } \\
\text { J.F.Macbr. }\end{array}$ & $\mathrm{H}$ & Liliaceae & & $1,2,3,2,6,7,8,9,10$ \\
\hline 295 & Scleria lithosperma (L.) Sw. & Sedges & Cyperaceae & & $1,7,9$ \\
\hline 296 & Scutia myrtina (Burm.f.) Kurz & $\mathrm{L}$ & Rhamnaceae & & 7,9 \\
\hline 297 & $\begin{array}{c}\text { Sebastiania chamaelea (L.) } \\
\text { Müll.Arg. }\end{array}$ & $\mathrm{H}$ & Euphorbiaceae & & 10 \\
\hline 298 & $\begin{array}{c}\text { Secamone emetica (Retz.) R. } \\
\text { Br. ex Schult. }\end{array}$ & $\mathrm{C}$ & Asclepiadaceae & & $1,3,6,7,8,9$ \\
\hline 299 & $\begin{array}{c}\text { Selaginella delicatula (Desv. ex } \\
\text { Poir.) Alston. }\end{array}$ & Fern & Selaginellaceae & & $1,7,8,9$ \\
\hline 300 & Sida acuta Burm.f. & $\mathrm{H}$ & Malvaceae & & $1,5,6,7,8,10$ \\
\hline 301 & $\begin{array}{l}\text { Sida cordata (Burm.f.) } \\
\text { Borss.Waalk. }\end{array}$ & $\mathrm{H}$ & Malvaceae & & $1,3,4,7,9,10$ \\
\hline 302 & Sida cordifolia L. & $\mathrm{H}$ & Malvaceae & & $1,2,3,6,7,8,9,10$ \\
\hline 303 & Sida mysorensis Wight \& Arn. & $\mathrm{H}$ & Malvaceae & & 6 \\
\hline 304 & Sida retusa $\mathrm{L}$. & $\mathrm{H}$ & Malvaceae & & 1,3 \\
\hline 305 & Solanum pubescens Willd. & $\mathrm{H}$ & Solanaceae & & $1,2,3,4,6,7,8,9,10$ \\
\hline 306 & Spermacoce articularis L.f. & $\mathrm{H}$ & Rubiaceae & & $1,5,6,7,8,9,10$ \\
\hline 307 & Spermacoce ocymoides Burm.f. & $\mathrm{H}$ & Rubiaceae & & $1,2,5,6,7,8,9,10$ \\
\hline 308 & Spermacoce stricta L.f. & $\mathrm{H}$ & Rubiaceae & & 1,5 \\
\hline 309 & Spilanthes calva DC. & $\mathrm{H}$ & Asteraceae & & 5 \\
\hline 310 & $\begin{array}{c}\text { Sporobolus coromandelianus } \\
\text { (Retz.) Kunth }\end{array}$ & Grass & Poaceae & & 4 \\
\hline 311 & $\begin{array}{c}\text { Sporobolus diandrus (Retz.) } \\
\text { P.Beauv. }\end{array}$ & Grass & Poaceae & & 6 \\
\hline 312 & Stemodia viscosa Roxb. & $\mathrm{H}$ & $\begin{array}{c}\text { Scrophulariace } \\
\text { ae }\end{array}$ & & 5 \\
\hline 313 & $\begin{array}{l}\text { Stenosiphonium russellianum } \\
\text { Nees }\end{array}$ & $\mathrm{H}$ & Acanthaceae & & 7 \\
\hline 314 & Streblus asper Lour. & $\mathrm{T}$ & Moraceae & & 7 \\
\hline
\end{tabular}




\begin{tabular}{|c|c|c|c|c|c|}
\hline 315 & Strychnos nux-vomica L. & $\mathrm{T}$ & Loganiaceae & & $1,2,7,8,10$ \\
\hline 316 & Strychnos potatorum L.f. & $\mathrm{T}$ & Loganiaceae & & $1,7,8,10$ \\
\hline 317 & $\begin{array}{c}\text { Stylosanthes fruticosa (Retz.) } \\
\text { Alston }\end{array}$ & $\mathrm{H}$ & Fabaceae & & 9 \\
\hline 318 & Syzygium cumini (L.) Skeels & $\mathrm{T}$ & Myrtaceae & & 5 \\
\hline 319 & Tamarindus indica $\mathrm{L}$. & $\mathrm{T}$ & Caesalpiniaceae & & $5,6,10$ \\
\hline 320 & $\begin{array}{c}\text { Tarenna asiatica (L.) Kuntze } \\
\text { ex K.Schum. }\end{array}$ & $S$ & Rubiaceae & & $1,2,3,6,7,8,9,10$ \\
\hline 321 & $\begin{array}{c}\text { Tecoma stans (L.) Juss. ex } \\
\text { Kunth }\end{array}$ & S & Bignoniaceae & & 1 \\
\hline 322 & Tectona grandis L.f. & $\mathrm{T}$ & Verbenaceae & & 2 \\
\hline 323 & Tephrosia pumila (Lam.) Pers. & $\mathrm{H}$ & Fabaceae & & $1,3,6,7,8,9,10$ \\
\hline 324 & Tephrosia purpurea (L.) Pers. & $\mathrm{H}$ & Fabaceae & & $1,2,6,8,9,10$ \\
\hline 325 & Tephrosia tinctoria Pers. & $\mathrm{H}$ & Fabaceae & & $1,2,6$ \\
\hline 326 & Tephrosia uniflora Pers. & $\mathrm{H}$ & Fabaceae & Rare & 2 \\
\hline 327 & Tephrosia villosa (L.) Pers. & $\mathrm{H}$ & Fabaceae & & 8 \\
\hline 328 & Teramnus mollis Benth. & $\mathrm{H}$ & Fabaceae & & 2 \\
\hline 329 & $\begin{array}{c}\text { Terminalia arjuna (Roxb.) } \\
\text { Wight \& Arn. }\end{array}$ & $\mathrm{T}$ & Combretaceae & NT & 5 \\
\hline 330 & $\begin{array}{l}\text { Theriophonum minutum } \\
\text { (Willd.) Baill. }\end{array}$ & $\mathrm{H}$ & Araceae & Rare & 1 \\
\hline 331 & $\begin{array}{c}\text { Tinospora cordifolia (Willd.) } \\
\text { Miers }\end{array}$ & $\mathrm{L}$ & $\begin{array}{c}\text { Menispermacea } \\
\text { e }\end{array}$ & & 3 \\
\hline 332 & $\begin{array}{l}\text { Toddalia asiatica var. gracilis } \\
\text { Gamble }\end{array}$ & $\mathrm{L}$ & Rutaceae & & $2,3,7,8,9,10$ \\
\hline 333 & Tragia involucrata $\mathrm{L}$. & $\mathrm{C}$ & Euphorbiaceae & & 3,9 \\
\hline 334 & Tragus roxburghii Panigrahi & Grass & Poaceae & & $6,8,9,10$ \\
\hline 335 & Tribulus lanuginosus $\mathrm{L}$. & $\mathrm{H}$ & Zygophyllaceae & $\begin{array}{c}\text { Endemi } \\
\qquad \mathrm{c}\end{array}$ & $1,7,10$ \\
\hline 336 & $\begin{array}{c}\text { Tribulus subramanyamii } \\
\text { P.Singh, G.S.Giri \& V.Singh }\end{array}$ & $\mathrm{H}$ & Zygophyllaceae & $\begin{array}{c}\text { Endemi } \\
\text { c }\end{array}$ & 8,9 \\
\hline 337 & Tribulus terrestris $\mathrm{L}$. & $\mathrm{H}$ & Zygophyllaceae & & $1,2,9,10$ \\
\hline 338 & $\begin{array}{l}\text { Trichodesma zeylanicum } \\
\text { (Burm.f.) R.Br. }\end{array}$ & $\mathrm{H}$ & Boraginaceae & & 9 \\
\hline 339 & Tridax procumbens $(\mathrm{L}.) \mathrm{L}$. & $\mathrm{H}$ & Asteraceae & & $1,3,8,10$ \\
\hline 340 & Triumfetta rhomboidea Jacq. & $\mathrm{H}$ & Tiliaceae & & 1,10 \\
\hline 341 & Triumfetta rotundifolia Lam. & $\mathrm{H}$ & Tiliaceae & Rare & 9 \\
\hline 342 & $\begin{array}{c}\text { Tylophora indica (Burm. f.) } \\
\text { Merr. }\end{array}$ & $\mathrm{C}$ & Asclepiadaceae & & $1,6,9$ \\
\hline 343 & Urginea indica (Roxb.) Kunth & $\mathrm{H}$ & Liliaceae & & $7,9,10$ \\
\hline 344 & $\begin{array}{c}\text { Ventilago maderaspatana } \\
\text { Gaertn. }\end{array}$ & $\mathrm{L}$ & Rhamnaceae & & 7 \\
\hline 345 & Vernonia cinerea (L.) Less. & $\mathrm{H}$ & Asteraceae & & $1,6,8,9,10$ \\
\hline 346 & Vicoa indica (L.) DC. & $\mathrm{H}$ & Asteraceae & & 1,4 \\
\hline 347 & Viscum orientale Willd. & $\mathrm{H}$ & Viscaceae & & 1 \\
\hline 348 & Waltheria indica $\mathrm{L}$. & $\mathrm{H}$ & Sterculiaceae & Rare & $6,9,10$ \\
\hline 349 & Wrightia tinctoria $\mathrm{R} . \mathrm{Br}$ & $\mathrm{T}$ & Apocynaceae & & $1,2,3,4,6,7,9,10$ \\
\hline 350 & Ziziphus oenopolia (L.) Mill. & $\mathrm{L}$ & Rhamnaceae & & $1,6,7,9,10$ \\
\hline 351 & Ziziphus trinervia Roth & $\mathrm{T}$ & Rhamnaceae & & $3,6,7,9$ \\
\hline 352 & Zornia diphylla (L.) Pers. & $\mathrm{H}$ & Fabaceae & & $2,8,9,10$ \\
\hline
\end{tabular}

1. CUTF: Carnatic umbrella thorn forest; 2. DDS: Dry deciduous scrub forest; 3. EuS: Euphorbia scrub forest; 4. HwkF:Hardwickia forest; 5. RvF: Riverain forest; 6. SDDF: Southern tropical dry deciduous forest; 7. SDMDF: Southern tropical dry moist mixed deciduous forest; 8. SDS: Southern scrub forest; 9. STF: Deccan thorn forest; 10. STS: Deccan thorn scrub forest. 